\title{
Just Passing Through: Archaeological Investigations of a Late Holocene Open Site in the Mitchell Grass Downs, Inland Northwest Queensland
}

\author{
Lynley A. Wallis ${ }^{1}$ and Sophie Collins ${ }^{2,3}$ \\ 1 Department of Archaeology, Flinders University, GPO Box 2100, Adelaide SA 5001, Australia \\ lynley.wallis@wallisheritageconsulting.com.au \\ 2 Cultural Heritage Management Australia, PO Box 9463, Deakin ACT 2600,Australia sophie.collins@me.com \\ 3 Archaeology and Natural History, School of Culture, History and Language, College of Asia and the Pacific, \\ The Australian National University, Canberra ACT 0200, Australia
}

\begin{abstract}
Comparatively little is known about the archaeology of the Mitchell Grass Downs region of inland Queensland. This paper reports the results of investigations of an open site complex therein, comprising numerous hearths, a human burial, middens, stone arrangements and a stone artefact assemblage. Analysis reveals the stone artefact assemblage is a palimpsest, representing multiple events in the late Holocene compressed into a single non-stratified archaeological surface assemblage. The evidence suggests use of the area was by highly mobile, transient populations passing through on an occasional seasonal basis when environmental conditions were amenable to travel; suggestions for a semi-sedentary population are not supported. Clear evidence for the extensive removal, weathering, reuse and recycling of artefacts has implications for our ability to reconstruct past human behaviours and landscape use in this region.
\end{abstract}

\section{Introduction}

The Mitchell Grass Downs (MGD) comprise an extensive belt of gently undulating plains stretching across western and north Queensland and into the Northern Territory. Although archaeological sites of inland northwest Queensland were first described in the early 1900s (e.g. Chisolm 1901, 1903; Gray 1913), limited systematic research has been undertaken here. It is clear that the uplands in the broader region have been occupied since at least 28,000 BP (Wallis et al. 2009; see also Davidson et al. 1993); however, the exploratory nature of the excavations conducted thus far, and the restricted array of cultural material recovered, allow few conclusions to be drawn about the extent or nature of regional Pleistocene occupation. In contrast, drawing on the results of development-related heritage surveys allows us a somewhat better understanding of the late Holocene archaeological record of the MGD proper (e.g. Bird 1997, 2000a, 2000b, 2000c; Border 1992; Border and Rowland 1990; Horsfall 1988; Lowe and Wallis 2012; Rosendahl and Wallis 2011; Rowland et al. 1994; Spencer 1994; Wallis 2011a, 2011b, 2011c). Here the most common site types are open, low density concentrations of predominantly silcrete and chert unretouched flakes and cores located on slightly elevated ridges or terraces in close proximity to watercourses. Such sites are probably mostly of mid-to-late Holocene antiquity, though this is typically assumed rather than demonstrated, since an absence of organic materials means they are not usually amenable to addressing questions of chronology. However, the artefact concentrations are sometimes associated with hearths and accumulations of freshwater mussel shells which do afford the opportunity to explore the antiquity of MGD occupation (cf. Crothers 1997; Holdaway et al. 2000, 2006; Simmons 2002; Spencer 1994). Wallis et al. (2004:70) carried out a detailed investigation of open site hearths in the MGD near the township of Richmond, concluding that: the sites were formed in a manner consistent with accounts provided in ethnohistorical sources. The radiocarbon ages obtained for seven of the hearths represent the first published dates of hearths in the MGD and provide irrefutable evidence of hearth construction during the late Holocene period, prior to and possibly into the early period of European contact ... The relatively low density of associated scatters suggests that these sites were not used repeatedly, but more likely on an irregular, short-term basis as people passed through the area.

The presence of painted and engraved art sites, burials, scarred trees, stone circles and other stone arrangements have also been recorded in the MGD, supporting the proposition that a range of social activities beyond merely economic activities were undertaken (Border and Rowland 1990). In fact, the extensive exchange networks documented by Roth (1897) in the ethnohistorical period as occurring in the west of the region likely spanned the entire MGD (Border 1992:23; Border and Rowland 1990:104). And, although sustained research has not been undertaken in the MGD, it has been argued that, in this region, people maintained a semi-sedentary existence in large base camps along the major waterholes through both summer and winter, with the period of greatest mobility occurring during the latter (Border and Rowland 1990:90).

This paper presents the results from studies undertaken between 2004 and 2006 under the auspices of a project titled Archaeological Investigations on Bora Station in the Mitchell Grass Downs, Northwest Queensland (referred to hereafter as the 'Bora Station Project'). Within the broad objective of exploring the nature of Aboriginal occupation in the northern MGD, the project more specifically aimed to: 


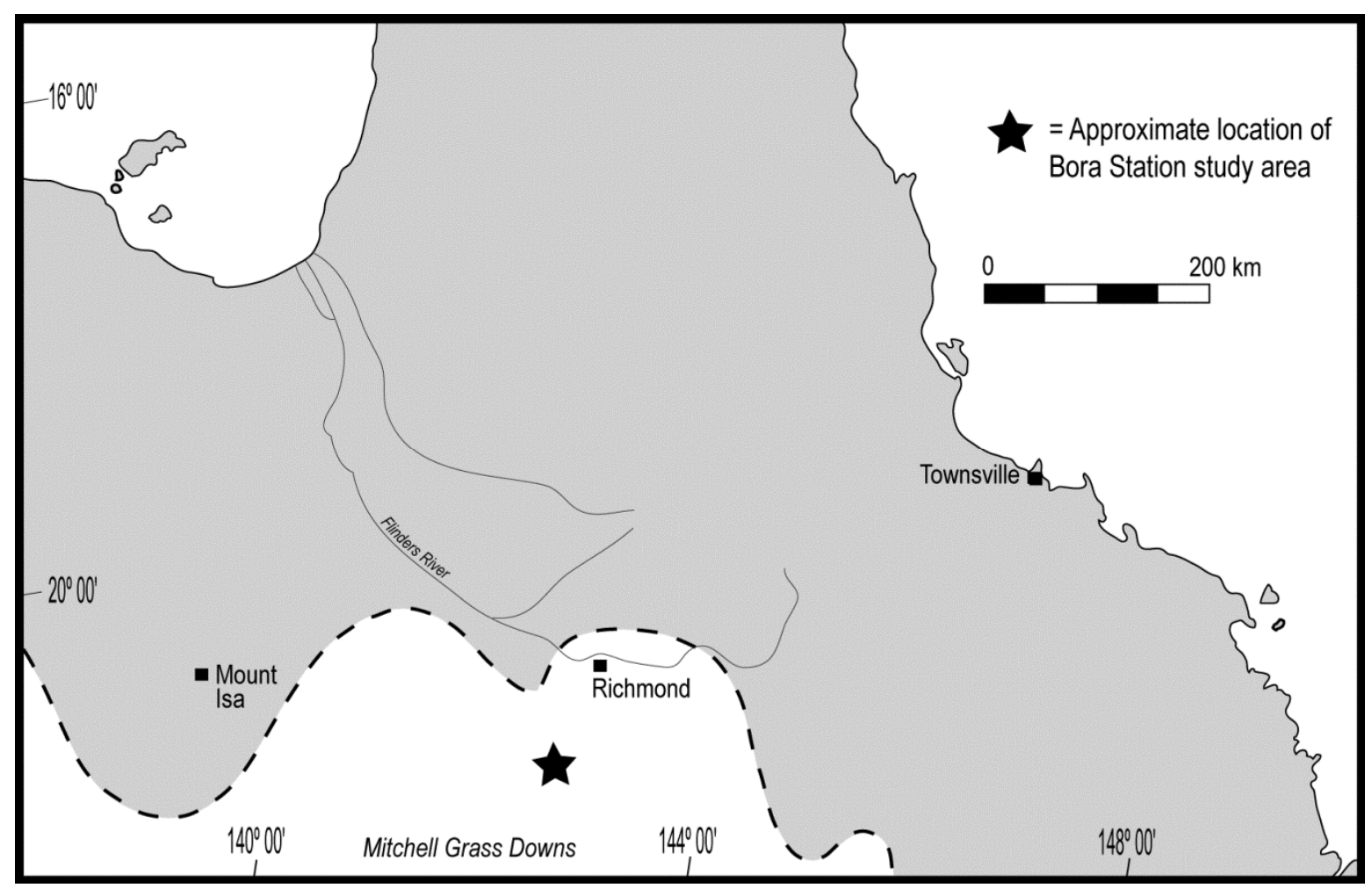

Figure 1. Location of the Bora Station study area in relation to the Mitchell Grass Downs biogeographic region, inland north Queensland.

- $\quad$ survey, record and define the spatial and temporal relationships of archaeological sites on Bora Station;

- undertake excavation and radiocarbon dating of hearth and midden features; and,

- undertake detailed analyses of stone artefact assemblages so as to better understand lithic production strategies and use patterns.

The antiquity of human use of the MGD, and the issue of whether evidence for semi-sedentary occupation of the region could be identified archaeologically were two of the broader research questions addressed.

\section{Background to the Study Area}

The MGD are characterised as comparatively homogenous low relief (180m to $200 \mathrm{~m}$ ASL) plains on the margin of the semi-arid zone (Twidale 1966). Geologically the area is dominated by Permian strata laid down in a shallow marine depositional environment; indeed, the area is well-known today for its exposed fossil-bearing deposits. The Allaru Mudstone formation (comprising claystone, calcareous sandstone, mudstone and siltstone) sits atop sandstones which comprise the Great Artesian aquifer; in turn these are underlain at depth by pre-Cambrian metamorphic rocks (Perry 1964; Vine 1970). Small outcrops of gravelly deposits, including siliceous and silcrete pebbles, also occur on some of the scattered terraces and low ridges throughout the MGD these were a valuable source of lithic raw materials for Aboriginal people.

Climatically the area features a short wet season and a long, comparatively cool dry season. Average rainfall is less than $600 \mathrm{~mm}$ per year, mostly falling between December and March, and it is not uncommon for the region to experience several consecutive years of drought.
Temperatures are consistently high, averaging above $30^{\circ} \mathrm{C}$ during the summer months and $17^{\circ} \mathrm{C}$ during winter, though frosts often occur.

Bora Station is in the northernmost extent of the Lake Eyre Basin catchment though no major rivers are present locally (Figure 1). The seasonal Rupert Creek is the main local watercourse (Figure 2), supported by a network of smaller, ephemeral feeder creeks and drainage lines that collectively, prior to European incursion in the latter half of the nineteenth century, would have supported a series of waterholes lasting through at least the early dry season. River flow throughout the MGD is intermittent due to the seasonal rainfall pattern, but when summer rains do arrive they result in widespread, shallow flooding. Evaporation rates are very high, however, meaning that surface waters dissipate relatively quickly. During flood events Aboriginal people would reportedly retreat to areas of higher country, returning as the waters receded (Wright 1988:42-43), though Roth (1897:132) pointed out that people's patterns of movement were driven by social and economic factors as much as prevailing environmental conditions.

The soils of the MGD are dominated by calcareous, cracking black clays with variable sand components (Perry 1964:19), an important consideration for archaeological site integrity. The regular swelling and shrinkage of such soils (depending on water content) causes large vertical cracks to appear. It is common for archaeological materials to fall down such cracks when they appear, and also for materials to be pushed upwards to the surface as the soil swells and the cracks reduce. Soil type is also an important determining factor in vegetation types (see below) and thus influences the local archaeological record in terms of both potential resource availability and ground surface visibility (GSV). 


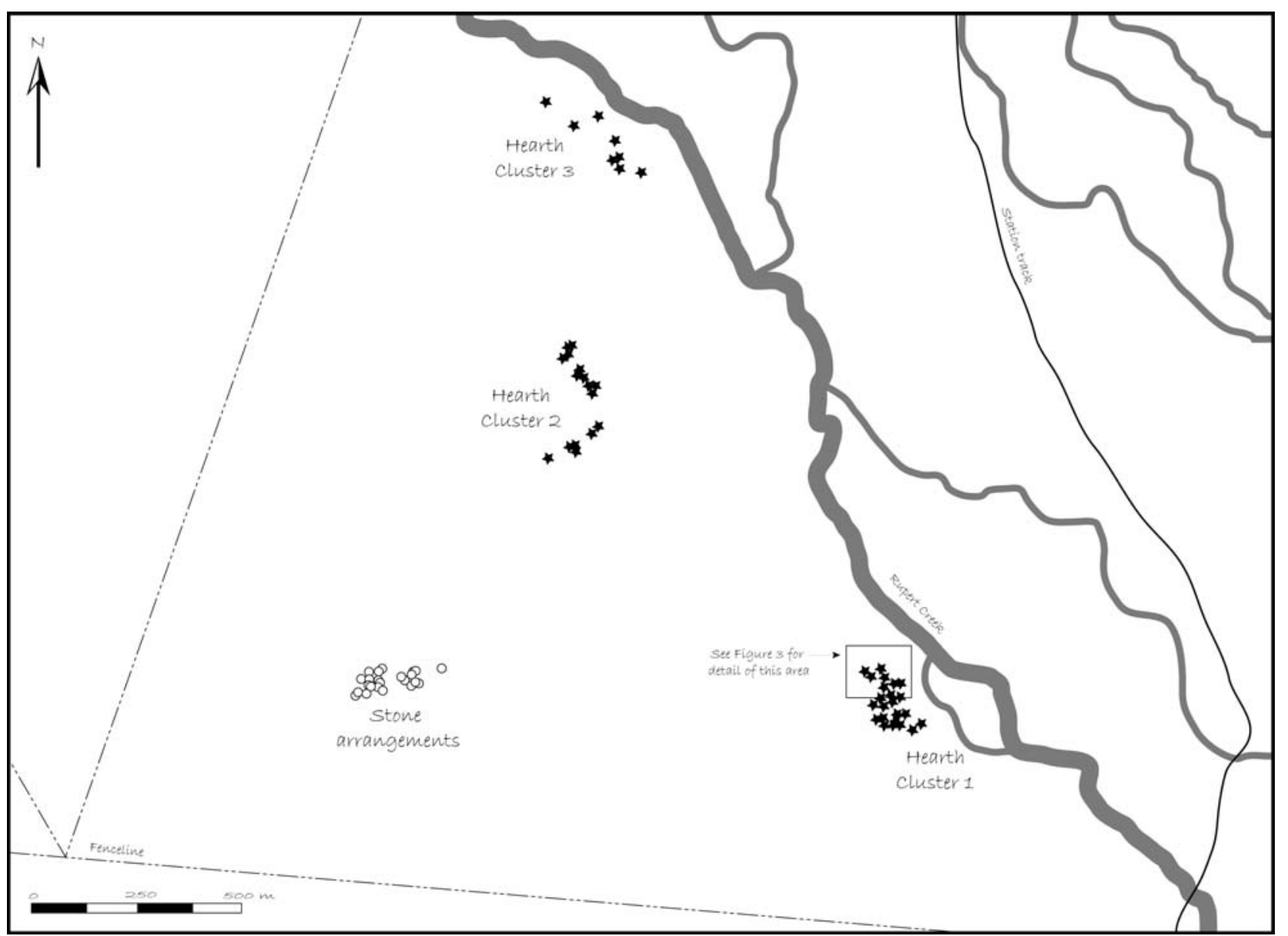

Figure 2. Locations of main archaeological features recorded on Bora Station.

The limited rainfall patterns have strongly influenced regional vegetation, which typically comprises grasslands or woodlands with a grassy understorey (Perry and Lazarides 1964), dominated by four species of tussock grasses after which the region is named: Astrebla pectinata (barley Mitchell), A. lappaceae (curly Mitchell), A. elymoides (weeping Mitchell) and A. squarrosa (bull Mitchell), with varying quantities of other species (Burbidge 1984; Neldner 1991; Slatyer 1964). Trees and shrubs are generally restricted to the watercourses, and are dominated by eucalypts, although other important species include Atalaya hemiglauca (whitewood), Lysiphyllum spp. (bauhinia), Grevillea spp., Hakea spp., Acacia farnesiana (prickly mimosa), Crotalaria spp. (rattlepods), Sesbania cannabina (pea bush) and Salsola koli (roly poly). Early explorers' reports make only general references to Aboriginal uses of plants in the region (e.g. Anon. 1861:21, 23; Landsborough 1862:22, 52, 78; McKinlay 1861-1862:64, 67, 70, 85, 92, 101, 124) and while seed-grinding implements are anecdotally reported to be relatively common (H. Smith, pers. comm., 2004), no such artefacts were observed during this project, probably because they were 'souvenired' during the early pastoral period.

The MGD supports a variety of animals, including the ubiquitous red and eastern grey kangaroos (Macropus rufus and $M$. giganteus) which were an important source of protein (e.g. Anon. 1861:21, 23; Landsborough 1862:9; McKinlay 1861-1862:9, 73, 75, 77, 79, 105, 107, 117). A number of smaller creatures are also present, including lizards (Varanidae, Agamidae and Scincidae families), snakes (Boidae family), dingoes (Canis familiaris), wallabies (Petrogale sp. and Macropus sp.), possums (Trichosaurus sp.), bandicoots (Isoodon sp.), mice (Muridae family), sugar-gliders (Petauridae family) and flying foxes (Pteropodidae family), and undoubtedly these too would have been targeted by Aboriginal people. Introduced species include cattle and sheep, with rabbits, camels, foxes, cats and pigs all representing challenging feral populations for heritage conservation in the area. Explorers regularly commented about the abundance of bird life around waterholes (e.g. Anon. 1861:19, 22; Landsborough 1862:9, 22; McKinlay 1861-1862:9, 62, 72, 100), which also supported yabbies (Parastacidae family). Most explorers also made reference to the widespread consumption of freshwater mussels (Velesunio sp.) and several species of fish (e.g. Anon. 1861:16; Landsborough 1862:39, 89, 90, 100; McKinlay 1861-1862:51, 69, 79, 83, 91, 92, 107) along the myriad of watercourses through the region.

The earliest European exploration in the area was that of Burke and Wills' ill-fated expedition of 1860-1861 (Anon. 1861), which saw them travel to the immediate west of Bora Station, followed by various rescue parties (Landsborough 1862; Laurie 1866; McKinlay 1861-1862; Walker 1862). Thereafter, accounts of 'the most perfect pastures for sheep and cattle' (Eden 1872:79) began trickling back to the southern settlements. Coupled with pressure exerted by expanding European pastoral interests in the Dalrymple and Kennedy Shires to the east, the Burke Pastoral District was officially declared opened in January 1864 (Allingham 1988:68; Holmes 1963:106; 
Meston 1895:49), with large runs immediately taken up. Nevertheless, the limited availability of surface water had an important impact, as following the initial forays of 1864-1865, a 10 year drought was experienced and many runs beyond the more reliable Flinders River were abandoned (Holmes 1963:107). Although runs were reestablished when the drought broke in the mid-1870s, it was only when artesian bores were sunk in the late 1800s that pastoralism gained a true foothold in the MGD.

\section{Methods}

The initial impetus for the Bora Station Project was a pastoralist report of an eroding burial (see Domett et al. 2006). At the request of members of the Wanamara People Core Country Native Title Claim, plans were made to carry out surveys, site recording and excavations in the burial vicinity. A targeted pedestrian survey was conducted along both sides of Rupert Creek to the southeast and northwest of the burial, for approximately $3 \mathrm{~km}$ and $7 \mathrm{~km}$, respectively. Handheld GPS recordings of archaeological features were entered into a GIS database and detailed plans were constructed using offset surveying and automatic level. Although it had been initially planned to pursue more extensive field surveys, discussions with local pastoralists revealed they were aware of only one other location on the property with archaeological potential. This second location was located approximately $15 \mathrm{~km}$ to the east of the burial site and was also subject to pedestrian survey and site recording. However, the comparatively low density of materials located in the latter, coupled with time constraints and the desire of community members to see the Rupert Creek burial and its associated features studied in-depth, precluded opportunities to conduct other reconnaissance work.

In order to determine a minimum age for use of the Rupert Creek site complex nine hearths (BH02, BH04, BH05, BH09 and BH13 from HC1 and BH31, BH32, BH42 and BH44 from HC2) were selected for excavation, following criteria and methods described in Wallis et al. (2004). In situ charcoal samples were also collected from under intact heat retainer stones from three additional hearths (BH01, BH15 and BH18 in HC1); many other hearths were examined in this fashion but did not preserve charcoal suitable for collection. One midden was subjected to a $50 \mathrm{~cm} \times 50 \mathrm{~cm}$ test excavation to obtain shell for dating purposes. A further two dating samples were also collected from a shell midden exposed in an erosion gully to the immediate southeast of the burial.

Seven $5 \mathrm{~m} \times 5 \mathrm{~m}$ sampling locations were established and all surface artefacts within them collected for laboratory analysis (five at the HC1 location, and one each at the HC2 and HC3 locations) (Figure 2). In considering the integrity of these lithic assemblages, in addition to the potential impact of cattle trampling, another factor that should be taken into account are the local soils. As noted earlier, seasonal swelling and shrinkage of the local soils results in the appearance and closure of vertical cracks into which artefacts can fall and, alternatively, be pushed upwards. As a result, there is a bias towards larger-sized artefacts being retained on the ground surface. Furthermore, smaller artefacts are less obvious during survey and thus less likely to be salvaged. During fieldwork we were very conscious of these factors. Given the excellent ground surface visibility conditions, and the fact that at least six team members scoured every square of the sampling areas at least once (meaning every square metre of the sampling squares was examined a minimum of six times at close range), we are confident that most, if not all, visible surface stone artefacts were salvaged.

Given the absence of formal tool types recovered, artefacts were separated into categories of flakes, cores, retouched flakes, flaked pieces, shatter and heat shatter in accordance with a materialist classificatory scheme, after Hiscock (2006). Given the difficulty in identifying humanly-produced shatter, the 'shatter' and 'heat shatter' categories were excluded from subsequent analyses. Other additional qualitative (diagnostic features) and quantitative (metrical) variables including raw material type, colour, artefact size and weight, presence or absence of damage, platform type, presence or absence of overhang removal, extent of decortication and termination type were recorded. Particular note was taken of weathering on the artefacts and any visible recycling of materials over time. Cores and retouched flakes were then subjected to more detailed analysis, recording the angle of retouch, length and depth of the retouched area (after Clarkson 2002), the number of flake scars and retouch orientation (unifacial or bifacial) for retouched flakes, and the number of platforms, number of scars removed, number of core rotations involved and the termination of the last scar for cores.

\section{Results \\ Site Survey}

Four main clusters of hearths associated with stone artefact concentrations were located along the southern margin of Rupert Creek (Figure 2). Owing to heavy pasture in some parts of the survey area, ground surface visibility was sometimes only $\sim 40 \%$, though not along margins of the creeklines, where it was typically $>90 \%$.

The most concentrated area of archaeological materials was designated 'Hearth Cluster 1' (HC1). This included the initially reported burial, at least 28 hearths, a series of freshwater mussel shell middens and stone artefacts across an area of approximately $300 \mathrm{~m}$ by $100 \mathrm{~m}$ (Figure 3). Middens 1 ('M1') and 2 ('M2') were apparent only as c.10cm-thick shell lenses exposed in section along the erosion line southeast of the burial. While recorded as discrete features it is possible they are exposures of a single midden (see radiocarbon determinations below). A third midden ('M3') was also located c. $25 \mathrm{~m}$ southwest of the burial. In this instance a low density scatter of highly fragmented mussel shell was observed on the surface and excavation revealed well-preserved intact valves preserved up to $10 \mathrm{~cm}$ beneath the ground surface.

A second cluster ('Hearth Cluster 2'; hereafter HC2) of at least 18 hearths and numerous stone artefacts in an area measuring approximately $200 \mathrm{~m}$ x 200m was located $1.2 \mathrm{~km}$ to the northwest of HC1. This cluster occurred on a low stony ridge between the southern margin of Rupert Creek and an un-named small creekline.

A third cluster of at least eight hearths associated with another concentration of stone artefacts spread over an area of approximately $200 \mathrm{~m}$ x 100m was located c.500m north of HC2 (and 1.5km northwest of HC1). This area was designated 'Hearth Cluster 3' (HC3). 


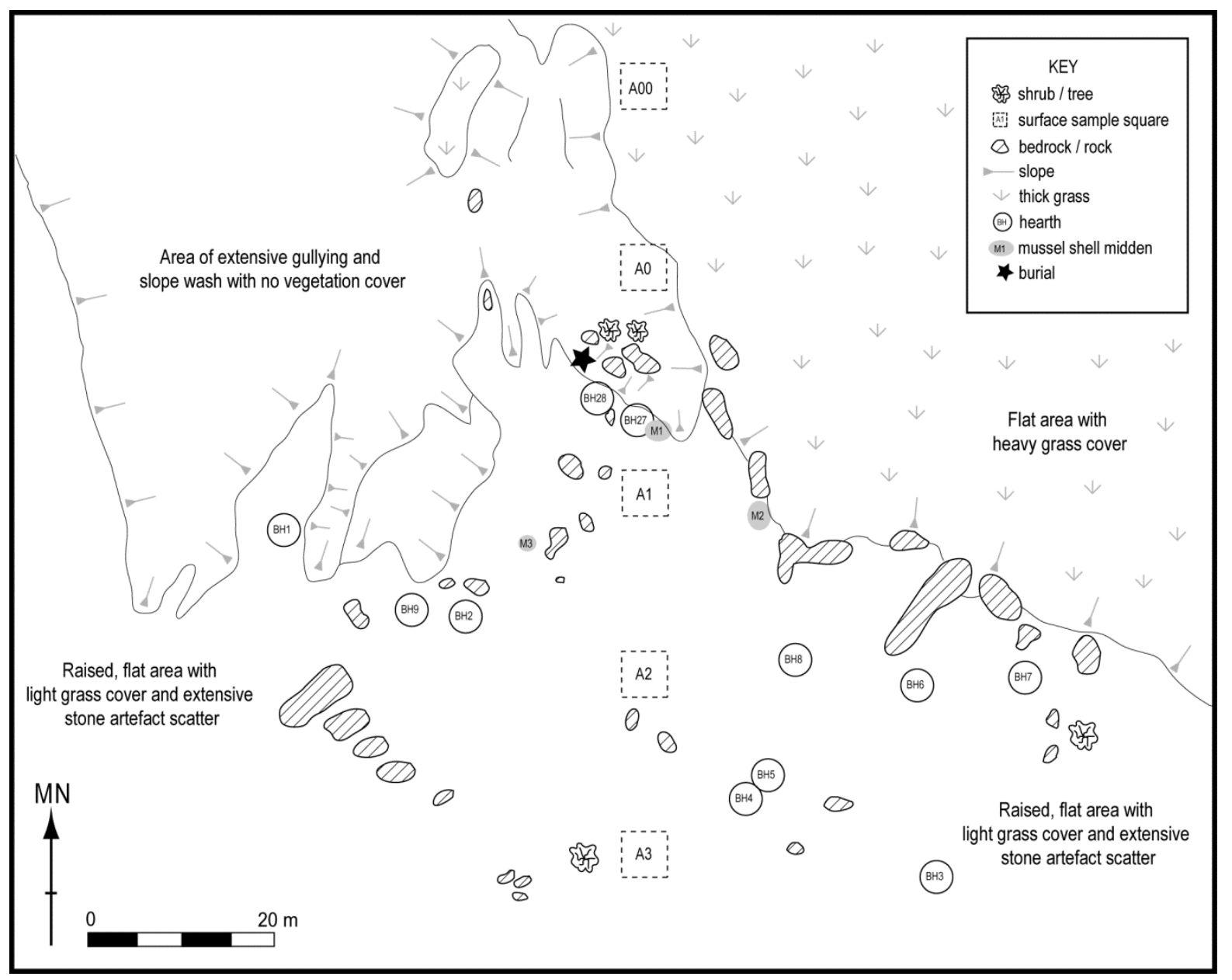

Figure 3. Detailed site plan of main area of Hearth Cluster 1 (HC1), including the five sample squares from which stone artefacts were collected for analysis.

A fourth cluster of very poorly preserved hearths and a low density artefact concentration was located c. $1 \mathrm{~km}$ further west of HC3. Here heat retainer stones were typically so dispersed that the original hearth location(s) could no longer be ascertained, though their cultural affinity was not in doubt owing to the distinctive colouring of the stones caused by high intensity burning (cf. Wallis et al. 2004). The poor preservation of features in this area is attributed to the fact that a cattle holding yard is present here, resulting in severe damage from continual treadage. It is not indicated on Figure 2 because it was not possible to collect material for dating or lithic analysis from this area owing to the highly disturbed nature of features here.

The only other archaeological features located during the pedestrian survey were several stone arrangements some obviously circular in plan view - situated along a slightly elevated ridge line up to $1 \mathrm{~km}$ to the southwest of Rupert Creek (Figure 2). Unfortunately there was not sufficient time available in which to carry out detailed investigations of these features. Each cluster was photographed and GPS readings taken and, at the request of the Woolgar Valley Aboriginal Corporation, funding will be sought to carry out detailed investigations here in future.

\section{Hearth Excavations}

Of the nine excavated hearths, only two (BH04 and BH05) contained mussel shell; all others contained only heat retainer stones and/or charcoal. Summary information about the excavated hearths is provided in Table 1. While elsewhere in the MGD hearths have been shown to extend up to $40 \mathrm{~cm}$ below ground surface (Wallis 2003; Wallis et al. 2004), at Bora they were generally much shallower than this, with only one exhibiting any depth $(\mathrm{c} .18 \mathrm{~cm}, \mathrm{BH} 44)$. This is probably due to the high levels of topsoil loss locally (cf. Simmons 2002), rather than differences in their original construction or use. In all instances the hearths appear to have been single-use - though only dating of multiple charcoal fragments from each hearth could confirm this unequivocally - shallow bowl-shaped depressions with locally available mudstone serving as the heat retaining source; sediment loss eventually caused the stones to spill outwards forming characteristic domed clusters of stones at the ground surface (Figure 4). There was a definite preference for heat retainers of a certain size and weight, with the majority having a maximum dimension between $61 \mathrm{~mm}$ and $100 \mathrm{~mm}$, and weighing between $51 \mathrm{~g}$ and $300 \mathrm{~g}$, though we note there may have been some fracturing during firing. The surface areas of the hearths range between c. $0.5 \mathrm{~m}^{2}$ and $3.0 \mathrm{~m}^{2}$, with an average of $1.41 \mathrm{~m}^{2}$. As one would expect, hearths with smaller surface areas were generally more intact, while those which had been disturbed by various processes were dispersed over a larger area of the site. 
Table 1. Summary information about excavated hearths.

\begin{tabular}{|c|c|c|c|c|c|c|c|}
\hline & & \multicolumn{2}{|c|}{ Hearth Dimensions } & \multicolumn{3}{c|}{ Surface Heat Retainers } \\
\hline Site & Location & $\begin{array}{c}\text { Length } \\
(\mathbf{m})\end{array}$ & $\begin{array}{c}\text { Width } \\
(\mathbf{m})\end{array}$ & $\begin{array}{c}\text { Area } \\
\left(\mathbf{m}^{\mathbf{2}}\right)\end{array}$ & $\begin{array}{c}\text { Average Weight } \\
(\mathbf{g})\end{array}$ & $\begin{array}{c}\text { Average Length } \\
(\mathbf{m m})\end{array}$ & Number \\
\hline BH02 & Hearth Cluster 1 & 1.5 & 1.0 & 1.50 & 494 & 108 & 20 \\
\hline BH04 & Hearth Cluster 1 & 0.8 & 0.6 & 0.48 & 359 & 98 & 16 \\
\hline BH05 & Hearth Cluster 1 & 1.6 & 0.8 & 1.28 & 217 & 83 & 38 \\
\hline BH09 & Hearth Cluster 1 & 1.7 & 1.1 & 1.87 & 1082 & 123 & 12 \\
\hline BH13 & Hearth Cluster 1 & 1.9 & 1.2 & 2.28 & 229 & 81 & 35 \\
\hline BH31 & Hearth Cluster 2 & 2.1 & 1.4 & 2.94 & 420 & 104 & 42 \\
\hline BH32 & Hearth Cluster 2 & 1.2 & 0.9 & 1.08 & 162 & 76 & 18 \\
\hline BH42 & Hearth Cluster 2 & 0.9 & 0.6 & 0.54 & 437 & 121 & 16 \\
\hline BH44 & Hearth Cluster 2 & 1.0 & 0.7 & 0.70 & 458 & 103 & 19 \\
\hline
\end{tabular}

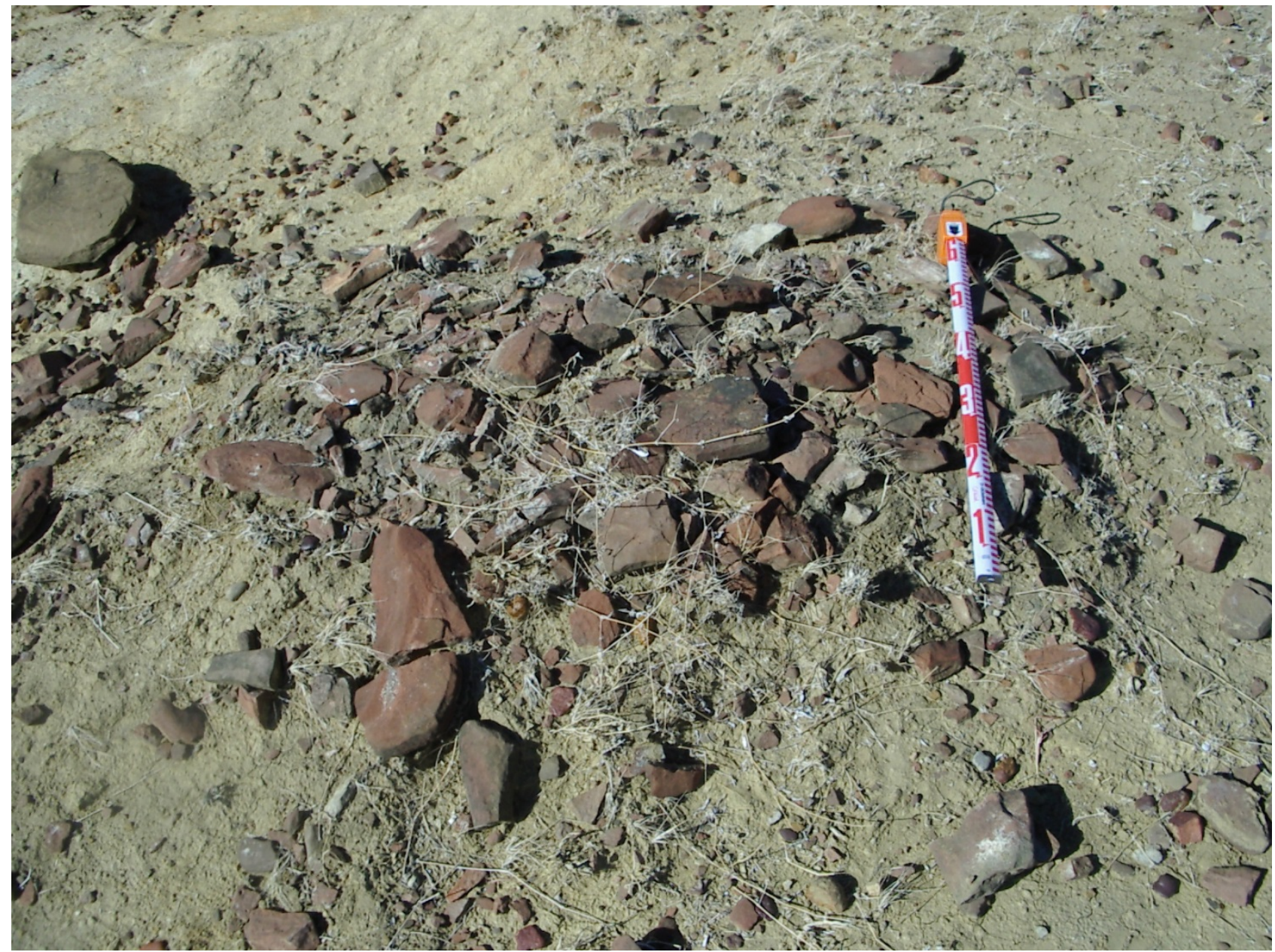

Figure 4. BH01, a typical heat retainer hearth such as commonly found on Bora Station. Facing north.

\section{Radiocarbon Determinations}

Radiocarbon results from the dated hearths and middens are shown in Table 2 and Figure 5. Dates were calibrated using the CALIB 5.0.1 program using the SHCal04.14c calibration curve for the southern hemisphere (McCormac et al. 2004). The hearths show a range of calibrated age estimates between c.160 BCE and 1805 AD, suggesting this area has been repeatedly visited since at least 1800 years ago. The overlapping determinations obtained from shell from M1 and M2 do not preclude the possibility that these are merely exposures of the same feature, though the absence of a continuous shell layer along the erosion face between them might discount this. While the age determination for M3 does overlap at two standard deviations with that obtained for M1, it seems more likely that this area of shells represents a different event.
Stone Artefact Analyses - Artefact Numbers, Densities, Classes and Raw Materials

A total of 1011 artefacts were collected and analysed from Bora Station: 519 from the five HC1 sample squares, and 265 and 227 from each sample square at HC2 and HC3, respectively (Table 3, Figure 6). At HC1 artefact densities ranged between 3 and $9 / \mathrm{m}^{2}$ depending on distance from the creekline, while at HC2 and HC3 they are at the high end of that range, at $10.5 / \mathrm{m}^{2}$ and $9 / \mathrm{m}^{2}$, respectively. No artefacts were recovered from HC1 Square A00; located in the gully the absence of artefacts here reflects the highly disturbed ground surface as a result of the ongoing erosion. As might be expected, there was a general decrease in artefact abundance across the site moving away from Rupert Creek. 
Table 2. Radiocarbon age estimates from hearths and freshwater mussel shell middens on Bora Station.

\begin{tabular}{|c|c|c|c|c|c|c|c|}
\hline Lab. No. & Site Code & $\begin{array}{c}\text { Hearth } \\
\text { Cluster \# }\end{array}$ & Material & $\begin{array}{c}\mathbf{\delta}^{\mathbf{1 3}} \mathbf{C} \\
\mathbf{( \% )}\end{array}$ & $\begin{array}{c}\mathbf{1}_{\mathbf{1 4}} \mathbf{C} \text { Age } \\
\text { (years BP) }\end{array}$ & $\begin{array}{c}\text { Calibrated Age AD } \\
\mathbf{9 5 . 4 \%}\end{array}$ & $\begin{array}{c}\text { Calibrated Age BP } \\
\mathbf{9 5 . 4 \%}\end{array}$ \\
\hline Wk-15561 & BH4 & 1 & Charcoal & $-24.9 \pm 0.2$ & $294 \pm 52$ & $1479-1805$ & $472-146$ \\
\hline Wk-15562 & BH5 & 1 & Charcoal & $-25.9 \pm 0.2$ & $535 \pm 63$ & $1310-1616$ & $640-335$ \\
\hline Wk-15559 & BH32 & 2 & Mussel shell & $-6.7 \pm 0.2$ & $544 \pm 35$ & $1396-1452$ & $554-498$ \\
\hline Wk-15563 & BH42 & 2 & Mussel shell & $-7.1 \pm 0.2$ & $1267 \pm 28$ & $694-892$ & $1256-1059$ \\
\hline Wk-15564 & BH1 & 1 & Charcoal & $-26.3 \pm 0.2$ & $1268 \pm 35$ & $687-895$ & $1263-1056$ \\
\hline Wk-15565 & BH15 & 1 & Charcoal & $-24.8 \pm 0.2$ & $1789 \pm 34$ & $221-410$ & $1729-1540$ \\
\hline ANU-2636 & BH18 & 1 & Charcoal & $-26.1 \pm 3.2$ & $2060 \pm 40$ & 160 BCE-83 AD & $2109-1868$ \\
\hline Wk-15556 & M1 & 1 & Mussel shell & $-6.6 \pm 0.2$ & $462 \pm 32$ & $1425-1616$ & $525-335$ \\
\hline Wk-15557 & M2 & 1 & Mussel shell & $-6.3 \pm 0.2$ & $517 \pm 52$ & $1325-1612$ & $625-338$ \\
\hline Wk-15558 & M3, Spit 2 & 1 & Mussel shell & $-6.5 \pm 0.2$ & $259 \pm 38$ & $1511-1951$ & $440-1$ \\
\hline
\end{tabular}

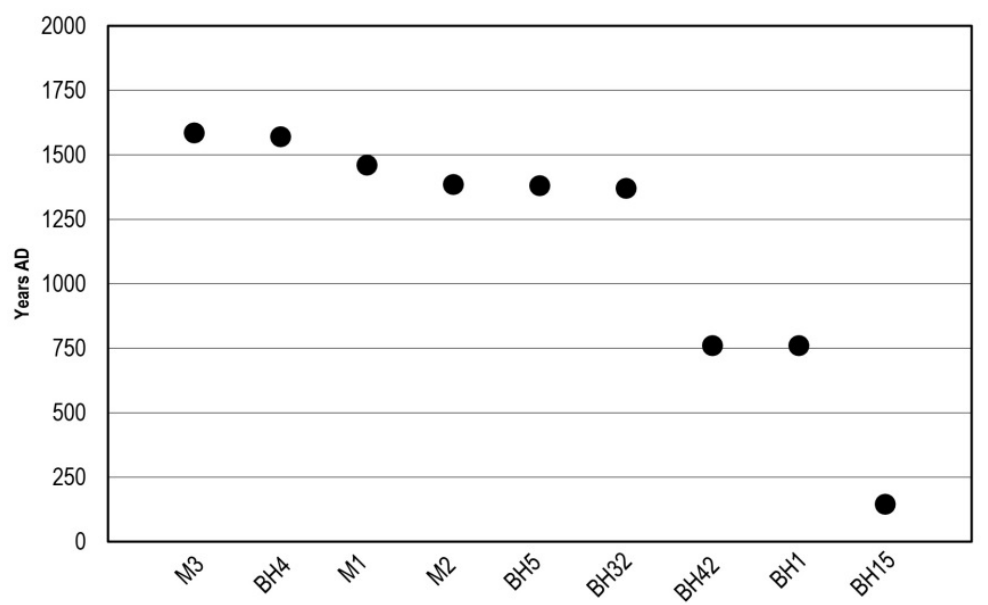

Figure 5. Radiocarbon dates (mid-point of 2-sigma calibrated age-range) from archaeological features, Bora Station.

Table 3. Combined numbers and percentages of stone artefact classes. Numbers in brackets indicate totals excluding shatter, heat shatter and flaked pieces, which were excluded from further analyses excepting those relating to raw material.

\begin{tabular}{|l|c|c|c|c|c|c|}
\hline & \multicolumn{2}{|c|}{ Hearth Cluster 1 } & \multicolumn{2}{c|}{ Hearth Cluster 2 } & \multicolumn{2}{c|}{ Hearth Cluster 3 } \\
\hline \multicolumn{1}{|c|}{ Artefact Class } & Number & Percentage & Number & Percentage & Number & Percentage \\
\hline Core & 134 & $26(29)$ & 58 & $22(26)$ & 42 & $19(21)$ \\
\hline Unretouched Flake & 232 & $45(50)$ & 102 & $38(46)$ & 97 & $43(48)$ \\
\hline Retouched Flake & 100 & $19(21)$ & 63 & $24(28)$ & 62 & $27(31)$ \\
\hline Flaked Piece & 18 & 3 & 33 & 12 & 8 & 4 \\
\hline Shatter & 22 & 4 & 6 & 2 & 12 & 5 \\
\hline Heat Shatter & 13 & 3 & 3 & 1 & 6 & 3 \\
\hline Total & $\mathbf{5 1 9 ( 4 6 6 )}$ & $\mathbf{1 0 0}$ & $\mathbf{2 6 5 ( 2 2 3 )}$ & $\mathbf{1 0 0}$ & $\mathbf{2 2 7}(\mathbf{2 0 1})$ & $\mathbf{1 0 0}$ \\
\hline
\end{tabular}

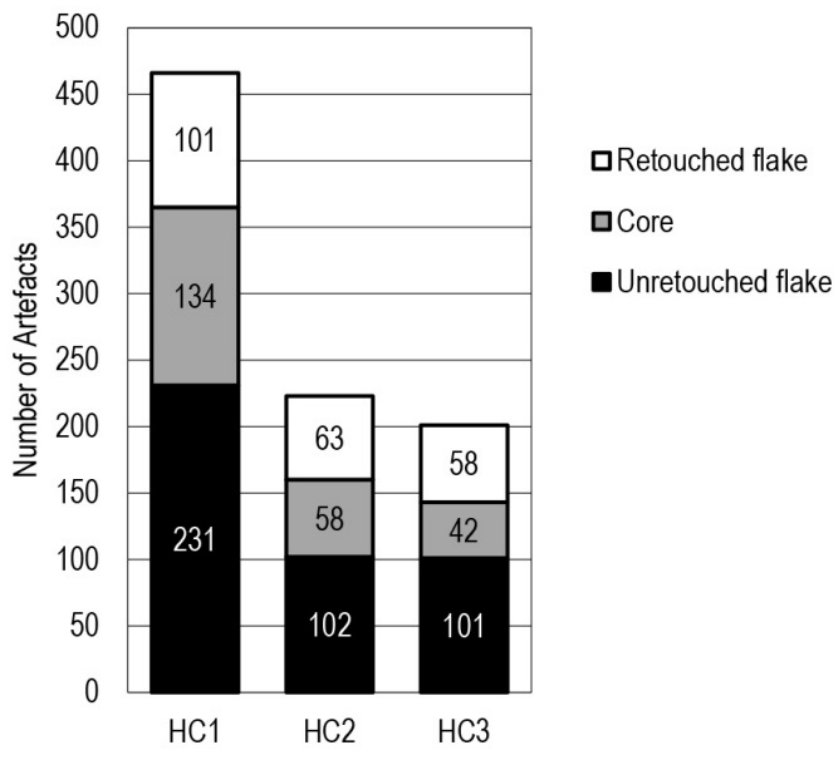

Figure 6. Major artefact class frequencies at Hearth Clusters 1, 2 and 3, Bora Station. 
Table 4. Artefact class relative to raw material abundance. In the final rows of the table (all three sites combined) numbers in brackets represent percentage values, and all raw materials other than silcrete and chert are classified together in the 'other' column.

\begin{tabular}{|c|c|c|c|c|c|c|c|c|}
\hline Site & Artefact Class & Silcrete & Chert & $\begin{array}{c}\text { Petrified } \\
\text { Wood }\end{array}$ & Chalcedony & Volcanic & Other & Total \\
\hline \multirow{7}{*}{ HC1 } & Core & 95 & 37 & 2 & 0 & 0 & 0 & 134 \\
\hline & Unretouched Flake & 130 & 94 & 2 & 1 & 0 & 0 & 232 \\
\hline & Retouched Flake & 64 & 39 & 1 & 0 & 0 & 1 & 100 \\
\hline & Flaked Piece & 12 & 3 & 0 & 0 & 3 & 0 & 18 \\
\hline & Shatter & 18 & 3 & 0 & 0 & 1 & 0 & 22 \\
\hline & Heat Shatter & 11 & 2 & 0 & 0 & 0 & 0 & 13 \\
\hline & Total & 330 & 178 & 5 & 1 & 4 & 1 & 519 \\
\hline \multirow{7}{*}{ HC2 } & Core & 45 & 13 & 0 & 0 & 0 & 0 & 58 \\
\hline & Unretouched Flake & 73 & 29 & 0 & 0 & 0 & 0 & 102 \\
\hline & Retouched Flake & 46 & 17 & 0 & 0 & 0 & 0 & 63 \\
\hline & Flaked Piece & 21 & 12 & 0 & 0 & 0 & 0 & 33 \\
\hline & Shatter & 3 & 0 & 0 & 0 & 0 & 0 & 3 \\
\hline & Heat Shatter & 4 & 1 & 0 & 0 & 1 & 0 & 6 \\
\hline & Total & 192 & 72 & $\mathbf{0}$ & $\mathbf{0}$ & 1 & $\mathbf{0}$ & 265 \\
\hline \multirow{7}{*}{ HC3 } & Core & 32 & 10 & 0 & 0 & 0 & 0 & 42 \\
\hline & Unretouched Flake & 61 & 39 & 0 & 0 & 0 & 1 & 97 \\
\hline & Retouched Flake & 40 & 17 & 0 & 0 & 1 & 0 & 62 \\
\hline & Flaked Piece & 6 & 2 & 0 & 0 & 0 & 0 & 8 \\
\hline & Shatter & 6 & 0 & 0 & 0 & 0 & 0 & 6 \\
\hline & Heat Shatter & 10 & 1 & 0 & 0 & 1 & 0 & 12 \\
\hline & Total & 155 & 69 & $\mathbf{0}$ & $\mathbf{0}$ & 2 & 1 & 227 \\
\hline \multirow{7}{*}{$\begin{array}{l}\text { All three } \\
\text { sites } \\
\text { combined }\end{array}$} & Core & $172(73.5)$ & $60(25.6)$ & & & & $2(0.9)$ & 234 \\
\hline & Unretouched Flake & $264(61.4)$ & $162(37.7)$ & & & & $4(0.9)$ & 430 \\
\hline & Retouched Flake & $150(66.4)$ & $73(32.3)$ & & & & $3(1.3)$ & 226 \\
\hline & Flaked Piece & $39(66.1)$ & $17(28.8)$ & & & & $3(5.1)$ & 59 \\
\hline & Shatter & 27 (87.1) & $3(9.7)$ & & & & $1(3.2)$ & 31 \\
\hline & Heat Shatter & $25(80.6)$ & $4(12.9)$ & & & & $2(6.5)$ & 31 \\
\hline & Total & 677 & 319 & & & & 15 & 1011 \\
\hline
\end{tabular}

As shown in Table 3, at all three localities, unretouched flakes represent between $38 \%$ and $45 \%$ of the total assemblage, with retouched flakes comprising between $21 \%$ and $31 \%$. The proportions of cores are relatively high at all three locations (between 21\% and $29 \%$ ), suggesting a moderate level of localised artefact production.

Figure 7 and Table 4 show the proportion of artefact classes by raw materials. Silcrete and chert are clearly dominant, with small quantities of other raw material types including brecciated chert, volcanics, an unknown siliceous material, chalcedony and silicified wood also present. The use of the various raw materials is roughly proportionate within each artefact category; however, there were slightly higher proportions of silcrete cores and, within the confines of the raw material, knappers showed a preference for chert when producing and retouching flakes. This is not unexpected, as the superiority of chert for knapping activities (Bamforth 1986; Holdaway and Stern 2004:19-29) suggests that, where possible, it will be used in preference to inferior materials, such as silcrete, as it has highly desirable flaking properties. Artefact sizes relative to raw material type likewise reveal consistent uses of both silcrete and chert, with similar proportions of each raw material present in each size category (Tables 5-6).

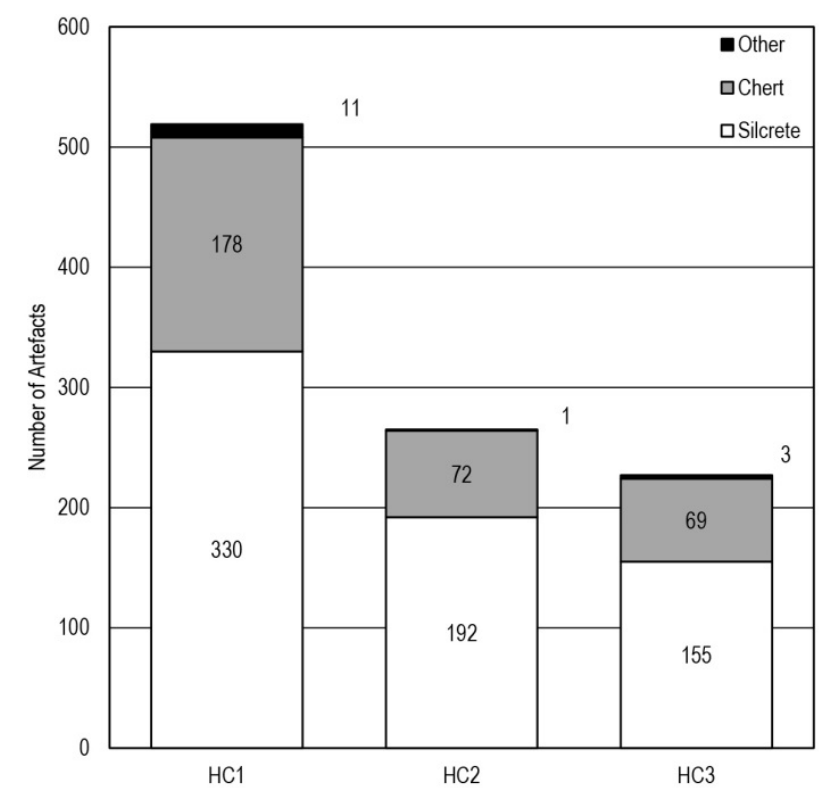

Figure 7. Raw material distributions of stone artefacts from HC1, HC2 and HC3, Bora Station. 
Table 5. Artefact class relative to size. Note that flaked pieces, shatter and heat shatter are excluded from this analysis.

\begin{tabular}{|c|c|c|c|c|c|c|c|c|c|}
\hline Site & $\begin{array}{c}\begin{array}{c}\text { Technological } \\
\text { Class }\end{array} \\
\end{array}$ & $<9.99 \mathrm{~mm}$ & $\begin{array}{c}10.0- \\
19.99 \mathrm{~mm}\end{array}$ & $\begin{array}{c}20.0- \\
29.99 \mathrm{~mm}\end{array}$ & $\begin{array}{c}30.0- \\
39.99 \mathrm{~mm}\end{array}$ & $\begin{array}{c}40.0- \\
49.99 \mathrm{~mm} \\
\end{array}$ & $\begin{array}{c}50.0- \\
59.99 \mathrm{~mm}\end{array}$ & $\begin{array}{c}60.0- \\
69.99 \mathrm{~mm} \\
\end{array}$ & Total \\
\hline \multirow{4}{*}{ HC1 } & Core & 0 & 24 & 60 & 35 & 10 & 2 & 1 & 132 \\
\hline & Retouched Flake & 1 & 35 & 37 & 16 & 2 & 0 & 0 & 91 \\
\hline & Unretouched Flake & 31 & 90 & 49 & 15 & 4 & 1 & 1 & 191 \\
\hline & Total & 32 & 149 & 146 & 66 & 16 & 3 & 2 & 414 \\
\hline \multirow{4}{*}{ HC2 } & Core & 1 & 14 & 22 & 12 & 5 & 2 & 1 & 57 \\
\hline & Retouched Flake & 3 & 24 & 21 & 11 & 3 & 0 & 0 & 62 \\
\hline & Unretouched Flake & 14 & 52 & 18 & 4 & 1 & 0 & 0 & 89 \\
\hline & Total & 18 & 90 & 61 & 27 & 9 & 2 & 1 & 208 \\
\hline \multirow{4}{*}{ HC3 } & Core & 0 & 9 & 18 & 7 & 4 & 4 & 0 & 42 \\
\hline & Retouched Flake & 2 & 19 & 22 & 9 & 2 & 0 & 0 & 54 \\
\hline & Unretouched Flake & 10 & 38 & 23 & 6 & 0 & 0 & 0 & 77 \\
\hline & Total & 12 & 66 & 63 & 22 & 6 & 4 & - & 173 \\
\hline \multicolumn{2}{|c|}{$\begin{array}{l}\text { Total (all three sites } \\
\text { combined) }\end{array}$} & 62 & 305 & 270 & 115 & 31 & 9 & 3 & 795 \\
\hline
\end{tabular}

Table 6. Raw material type relative to artefact size.

\begin{tabular}{|c|c|c|c|c|c|c|c|c|c|}
\hline Site & Raw Material & $<9.99 \mathrm{~mm}$ & $\begin{array}{c}10.0- \\
19.99 \mathrm{~mm}\end{array}$ & $\begin{array}{c}20.0- \\
29.99 \mathrm{~mm}\end{array}$ & $\begin{array}{c}\text { 30.0- } \\
39.99 \mathrm{~mm}\end{array}$ & $\begin{array}{c}40.0- \\
49.99 \mathrm{~mm}\end{array}$ & $\begin{array}{c}50.0- \\
59.99 \mathrm{~mm}\end{array}$ & $\begin{array}{c}60.0- \\
69.99 \mathrm{~mm}\end{array}$ & Total \\
\hline \multirow{4}{*}{ HC1 } & Chert & 12 & 66 & 43 & 20 & 5 & 1 & 0 & 147 \\
\hline & Silcrete & 19 & 82 & 101 & 46 & 10 & 2 & 2 & 262 \\
\hline & Other & 1 & 1 & 2 & 0 & 1 & 0 & 0 & 5 \\
\hline & Total & 32 & 149 & 146 & 66 & 16 & 3 & 2 & 414 \\
\hline \multirow{4}{*}{ HC2 } & Chert & 3 & 27 & 11 & 4 & 3 & 2 & 0 & 50 \\
\hline & Silcrete & 15 & 63 & 50 & 23 & 5 & 0 & 1 & 157 \\
\hline & Other & 0 & 0 & 0 & 0 & 1 & 0 & 0 & 1 \\
\hline & Total & 18 & 90 & 61 & 27 & 9 & 2 & 1 & 208 \\
\hline \multirow{4}{*}{ HC3 } & Chert & 3 & 19 & 22 & 8 & 0 & 1 & 0 & 53 \\
\hline & Silcrete & 9 & 46 & 40 & 14 & 6 & 3 & 0 & 118 \\
\hline & Other & 0 & 1 & 1 & 0 & 0 & 0 & 0 & 2 \\
\hline & Total & 12 & 66 & 63 & 22 & 6 & 4 & $\mathbf{0}$ & 173 \\
\hline \multicolumn{2}{|c|}{$\begin{array}{l}\text { Total (all three sites } \\
\text { combined) }\end{array}$} & 62 & 305 & 270 & 115 & 31 & 9 & 3 & 795 \\
\hline
\end{tabular}

Table 7. Decortification counts for all artefact classes relative to raw material type.

\begin{tabular}{|c|l|c|c|c|c|}
\hline & & \multicolumn{3}{|c|}{ Decortification } & \\
\hline Site & Raw Material & Tertiary & Secondary & Primary & Total \\
\hline \multirow{4}{*}{ HC1 1} & Chert & 29 & 116 & 2 & 147 \\
\cline { 2 - 6 } & Silcrete & 20 & 238 & 4 & 262 \\
\cline { 2 - 6 } & Other & 2 & 3 & 0 & 5 \\
\cline { 2 - 6 } & Total & $\mathbf{5 1}$ & $\mathbf{3 5 7}$ & $\mathbf{6}$ & $\mathbf{4 1 4}$ \\
\hline \multirow{4}{*}{ HC2 } & Chert & 14 & 35 & 1 & 50 \\
\cline { 2 - 6 } & Silcrete & 30 & 124 & 3 & 157 \\
\cline { 2 - 6 } & Other & 0 & 1 & 0 & 1 \\
\cline { 2 - 6 } & Total & $\mathbf{4 4}$ & $\mathbf{1 6 0}$ & $\mathbf{4}$ & $\mathbf{2 0 8}$ \\
\hline \multirow{4}{*}{ HC3 } & Chert & 9 & 44 & 0 & 53 \\
\cline { 2 - 6 } & Silcrete & 23 & 92 & 3 & 118 \\
\cline { 2 - 6 } & Other & $\mathbf{3 2}$ & $\mathbf{1 3 8}$ & $\mathbf{3}$ & $\mathbf{1 7 3}$ \\
\cline { 2 - 6 } & Total & 127 & 655 & 13 & 795 \\
\hline \multirow{2}{*}{$\begin{array}{l}\text { Total } \\
\text { combined) }\end{array}$} & (all three sites & & & & \\
\hline
\end{tabular}




\section{Stone Artefact Analyses - Reduction Indices}

Based on analysis of only the complete flakes and cores in the assemblages, reduction indices and decortification measurements reveal predominantly similar patterns of raw material use, production and transport at $\mathrm{HC} 1, \mathrm{HC} 2$ and HC3.

Moderate levels of reduction occurred at HC1, with only $1 \%$ of artefacts showing primary decortification, and just under $13 \%$ showing tertiary levels of decortication (Table 7). It therefore seems probable that some artefacts were partially reduced or decorticated prior to their arrival at this locality. As noted above, retouched flakes and cores appear in large numbers at HC1, suggesting relatively high levels of reduction, however, analyses of each artefact type separately suggests only moderate reduction, with retouch only minimally invasive and cores discarded prior to exhaustion. At the HC2 location tertiary reduction is much higher. Proportionately, chert flakes experience slightly higher levels of primary reduction than silcrete while reduction measures indicate a slight preference for silcrete. At the HC3 location, tertiary reduction is quite high, with a larger proportion of tertiary reduction occurring on silcrete flakes (25\%) relative to chert flakes (17\%). Primary reduction is again fairly low and is more common on chert flakes.

Dorsal scar numbers on complete unretouched and retouched flakes range between 0 and 52, with chert flakes sustaining proportionately larger numbers of dorsal scars than those of silcrete (Table 8). The number of flakes removed from cores ranged from 1 to 41 and involved up to 7 rotations (Tables 9 and 10). On average, cores from HC1 displayed 2 to 9 scars from 3 or 4 rotations, yet $95 \%$ of them showed only secondary levels of decortication, indicating that many of them had not been exhausted at discard. Dorsal scars on HC2 flakes range between 0 and 17 (with the greatest reduction occurring on silcrete flakes), though most flakes exhibit between 2 and 6 scars. Core scar numbers on the 57 cores in the HC2 assemblage show from 2 to 14 flake removals. Chert cores represent $21 \%$ of those found at the site, of which $84 \%$ incurred 6 or more scars, yet silcrete cores are the more heavily reduced, with $20 \%$ of the latter having 1 or more scars. Core rotations range between 0 and 6 , and most commonly between 2 and 4 times regardless of their raw material. Differences in the treatment of raw materials are not apparent. Dorsal scar numbers on complete flakes at HC3 reveal up to 31 scars prior to the manufacture of each flake. The proportion of flakes exceeding 6 scars is much greater on chert than on silcrete. Core scar numbers range between 2 and 22 from up to 7 rotations within the HC3 assemblage. Of the 42 cores recovered, $25 \%$ were of chert, including the core with the greatest number of scar removals. Most cores exhibited between 6 and 10 scars from 3 or 4 rotations, regardless of the raw material utilised. Despite the high scar numbers at this location, only $12 \%$ of the cores recovered achieved tertiary levels of decortication, with the rest retaining secondary levels of cortex and again being discarded prior to exhaustion.

Preferential reduction of cores relative to raw material type is not apparent in any of the artefact concentrations, with core sizes closely correlated with the amount of reduction evidenced - smaller cores display higher numbers of scars and rotations than larger cores (Table 11).

Retouched flakes within the HC1 assemblage show moderate levels of reduction, with a maximum of 13 segments affected by retouch on any one flake (Table 12). Retouched flake frequencies are higher for the HC2 assemblage than is apparent at HC1. While retouch most commonly affected only one segment of retouched flakes for both materials at $\mathrm{HC} 2$, up to 6 segments were retouched on silcrete flakes and up to 4 segments on chert flakes. These measurements indicate low to moderate levels of reduction at HC2. Despite high frequencies of retouched artefacts in the HC3 assemblage, invasiveness measurements are again relatively low, with retouch affecting only 1 or 2 segments of the edge in most instances.

\section{Stone Artefact Analyses - Core:Flake Ratios}

Core:flake ratios are a useful measure as they provide an indication of the levels of on-site artefact production. Table 13 summarises the ratios of cores to flakes, relative to raw material, at each of the three locations. These figures are based on MNI estimates, i.e. the number of complete flakes plus the greatest number of proximal or distal portions from transversely broken artefacts, plus the greatest number of left or right lateral portions from longitudinally snapped flakes. Table 13 demonstrates that, for silcrete and chert, the number of flakes present could easily have been produced by the number of cores present at the site. In fact, given the high numbers of dorsal scarring on flakes, as well as high levels of decortication, it is likely that many more flakes were once present than were collected. This discrepancy is likely due to the effects of post-depositional processes operating in this regularly inundated area, where small flakes in particular are susceptible to water movement.

Core:flake ratios indicate that, on average, there is one core for every 2.4 flakes recovered. Core scar numbers, however, suggest that a minimum of 918 flakes were struck from the cores, with an average of 7 scars on each core. Even allowing for broken flakes to contribute to the core:flake ratios, it is clear that many of the flakes represented by the cores are missing from the assemblages. This evidence suggests material transport to and from these locations, with less than half of the flakes evidenced on cores recovered. Also, volcanic flakes exist that have no cores present from which they could have been produced. It is possible that flakes (and volcanic cores) have either been (1) lost through post-depositional processes, (2) produced and discarded elsewhere with the core alone being transported, or (3) produced on site (where the core was discarded) and transported for discard and use elsewhere. 
Table 8. Dorsal scar count by raw material (for complete flakes only).

\begin{tabular}{|c|c|c|c|c|c|}
\hline & & \multicolumn{4}{|c|}{ Raw Material } \\
\hline Site & $\begin{array}{l}\text { Number of } \\
\text { Dorsal Scars }\end{array}$ & Other & Chert & Silcrete & Total \\
\hline \multirow{14}{*}{ HC1 } & 0 & 0 & 5 & 10 & 15 \\
\hline & 1 & 0 & 9 & 20 & 29 \\
\hline & 2 & 2 & 10 & 30 & 42 \\
\hline & 3 & 0 & 24 & 36 & 60 \\
\hline & 4 & 0 & 17 & 24 & 41 \\
\hline & 5 & 0 & 14 & 22 & 36 \\
\hline & 6 & 0 & 7 & 9 & 16 \\
\hline & 7 & 1 & 13 & 6 & 20 \\
\hline & 8 & 0 & 6 & 4 & 10 \\
\hline & 9 & 0 & 3 & 3 & 6 \\
\hline & 10 & 0 & 0 & 2 & 2 \\
\hline & 11 & 0 & 3 & 1 & 4 \\
\hline & 13 & 0 & 0 & 1 & 1 \\
\hline & Total & 3 & 111 & 168 & 282 \\
\hline \multirow{13}{*}{ HC2 } & 0 & 0 & 1 & 4 & 5 \\
\hline & 1 & 0 & 3 & 11 & 14 \\
\hline & 2 & 1 & 6 & 21 & 28 \\
\hline & 3 & 0 & 7 & 23 & 30 \\
\hline & 4 & 0 & 7 & 12 & 19 \\
\hline & 5 & 0 & 4 & 23 & 27 \\
\hline & 6 & 0 & 7 & 7 & 14 \\
\hline & 7 & 0 & 1 & 5 & 6 \\
\hline & 8 & 0 & 1 & 2 & 3 \\
\hline & 9 & 0 & 0 & 3 & 3 \\
\hline & 11 & 0 & 0 & 1 & 1 \\
\hline & 17 & 0 & 0 & 1 & 1 \\
\hline & Total & 1 & 37 & 113 & 151 \\
\hline \multirow{19}{*}{ HC3 } & 0 & 0 & 2 & 6 & 8 \\
\hline & 1 & 0 & 0 & 6 & 6 \\
\hline & 2 & 1 & 5 & 12 & 18 \\
\hline & 3 & 0 & 6 & 15 & 21 \\
\hline & 4 & 0 & 6 & 15 & 21 \\
\hline & 5 & 0 & 7 & 16 & 23 \\
\hline & 6 & 0 & 4 & 2 & 6 \\
\hline & 7 & 0 & 2 & 5 & 7 \\
\hline & 8 & 0 & 3 & 3 & 6 \\
\hline & 9 & 0 & 3 & 0 & 3 \\
\hline & 10 & 0 & 0 & 2 & 2 \\
\hline & 11 & 0 & 2 & 1 & 3 \\
\hline & 12 & 0 & 1 & 0 & 1 \\
\hline & 13 & 1 & 1 & 0 & 2 \\
\hline & 14 & 0 & 1 & 0 & 1 \\
\hline & 21 & 0 & 0 & 1 & 1 \\
\hline & 31 & 0 & 1 & 0 & 1 \\
\hline & 52 & 0 & 0 & 1 & 1 \\
\hline & Total & 2 & 43 & 86 & 131 \\
\hline \multicolumn{2}{|c|}{$\begin{array}{l}\text { Total (all three sites } \\
\text { combined) }\end{array}$} & 6 & 191 & 367 & 564 \\
\hline
\end{tabular}


Table 9. Flake removal count by raw material (for cores only).

\begin{tabular}{|c|c|c|c|c|c|}
\hline \multirow[b]{2}{*}{ Site } & \multirow[b]{2}{*}{$\begin{array}{c}\text { Number of } \\
\text { Flake Removals }\end{array}$} & \multicolumn{4}{|c|}{ Raw Material } \\
\hline & & Other & Chert & Silcrete & Total \\
\hline \multirow{20}{*}{ HC1 } & 1 & 0 & 2 & 5 & 7 \\
\hline & 2 & 0 & 2 & 10 & 12 \\
\hline & 3 & 0 & 2 & 8 & 10 \\
\hline & 4 & 0 & 1 & 13 & 14 \\
\hline & 5 & 0 & 1 & 9 & 10 \\
\hline & 6 & 1 & 2 & 8 & 11 \\
\hline & 7 & 0 & 7 & 9 & 16 \\
\hline & 8 & 0 & 4 & 7 & 11 \\
\hline & 9 & 0 & 2 & 9 & 11 \\
\hline & 10 & 0 & 1 & 4 & 5 \\
\hline & 11 & 0 & 1 & 2 & 3 \\
\hline & 12 & 0 & 2 & 1 & 3 \\
\hline & 13 & 0 & 2 & 2 & 4 \\
\hline & 14 & 1 & 2 & 2 & 5 \\
\hline & 16 & 0 & 1 & 1 & 2 \\
\hline & 17 & 0 & 0 & 1 & 1 \\
\hline & 18 & 0 & 2 & 2 & 4 \\
\hline & 22 & 0 & 0 & 1 & 1 \\
\hline & 41 & 0 & 0 & 1 & 1 \\
\hline & Total & 2 & 34 & 95 & 141 \\
\hline \multirow{13}{*}{ HC2 } & 2 & 0 & 1 & 0 & 1 \\
\hline & 4 & 0 & 1 & 1 & 2 \\
\hline & 5 & 0 & 0 & 8 & 8 \\
\hline & 6 & 0 & 3 & 5 & 8 \\
\hline & 7 & 0 & 0 & 6 & 6 \\
\hline & 8 & 0 & 1 & 7 & 8 \\
\hline & 9 & 0 & 5 & 8 & 13 \\
\hline & 10 & 0 & 1 & 1 & 2 \\
\hline & 11 & 0 & 0 & 2 & 2 \\
\hline & 12 & 0 & 0 & 3 & 3 \\
\hline & 13 & 0 & 0 & 2 & 2 \\
\hline & 14 & 0 & 0 & 2 & 2 \\
\hline & Total & 0 & 12 & 45 & 57 \\
\hline \multirow{15}{*}{ HC3 } & 2 & 0 & 0 & 2 & 2 \\
\hline & 3 & 0 & 0 & 3 & 3 \\
\hline & 4 & 0 & 0 & 3 & 3 \\
\hline & 5 & 0 & 0 & 1 & 1 \\
\hline & 6 & 0 & 2 & 1 & 3 \\
\hline & 7 & 0 & 1 & 4 & 5 \\
\hline & 8 & 0 & 2 & 5 & 7 \\
\hline & 9 & 0 & 1 & 5 & 6 \\
\hline & 10 & 0 & 1 & 3 & 4 \\
\hline & 11 & 0 & 0 & 1 & 1 \\
\hline & 12 & 0 & 0 & 2 & 2 \\
\hline & 13 & 0 & 1 & 1 & 2 \\
\hline & 16 & 0 & 0 & 2 & 2 \\
\hline & 21 & 0 & 1 & 0 & 1 \\
\hline & Total & $\mathbf{0}$ & 9 & 33 & 42 \\
\hline \multicolumn{2}{|c|}{$\begin{array}{l}\text { Total (all three sites } \\
\text { combined) }\end{array}$} & 2 & 57 & 173 & 230 \\
\hline
\end{tabular}


Table 10. Number of core rotations by raw material type.

\begin{tabular}{|c|c|c|c|c|c|}
\hline & & \multicolumn{4}{|c|}{ Raw Material } \\
\hline Site & $\begin{array}{c}\text { Number of } \\
\text { Flake Removals }\end{array}$ & Other & Chert & Silcrete & Total \\
\hline \multirow{9}{*}{ HC1 } & 0 & 0 & 2 & 8 & 10 \\
\hline & 1 & 0 & 3 & 17 & 20 \\
\hline & 2 & 0 & 2 & 10 & 12 \\
\hline & 3 & 2 & 9 & 28 & 39 \\
\hline & 4 & 0 & 13 & 25 & 38 \\
\hline & 5 & 0 & 3 & 5 & 8 \\
\hline & 6 & 0 & 0 & 2 & 2 \\
\hline & 7 & 0 & 2 & 0 & 2 \\
\hline & Total & 2 & 34 & 95 & 131 \\
\hline \multirow{8}{*}{ HC2 } & 0 & 0 & 0 & 1 & 1 \\
\hline & 1 & 0 & 1 & 1 & 2 \\
\hline & 2 & 0 & 2 & 4 & 6 \\
\hline & 3 & 0 & 4 & 10 & 14 \\
\hline & 4 & 0 & 5 & 18 & 23 \\
\hline & 5 & 0 & 0 & 9 & 9 \\
\hline & 6 & 0 & 0 & 2 & 2 \\
\hline & Total & $\mathbf{0}$ & 12 & 45 & 57 \\
\hline \multirow{8}{*}{ HC3 } & 1 & 0 & 1 & 4 & 5 \\
\hline & 2 & 0 & 2 & 4 & 6 \\
\hline & 3 & 0 & 3 & 4 & 7 \\
\hline & 4 & 0 & 2 & 15 & 17 \\
\hline & 5 & 0 & 0 & 4 & 4 \\
\hline & 6 & 0 & 1 & 1 & 2 \\
\hline & 7 & 0 & 0 & 1 & 1 \\
\hline & Total & 0 & 9 & 33 & 42 \\
\hline \multicolumn{2}{|c|}{$\begin{array}{l}\text { Total (all three sites } \\
\text { combined) }\end{array}$} & 2 & 55 & 173 & 230 \\
\hline
\end{tabular}

Table 11. Maximum length of cores by raw material type.

\begin{tabular}{|c|c|c|c|c|c|c|c|c|c|}
\hline Site & Raw Material & $<9.99 \mathrm{~mm}$ & $\begin{array}{c}10.0- \\
19.99 \mathrm{~mm}\end{array}$ & $\begin{array}{c}20.0- \\
29.99 \mathrm{~mm}\end{array}$ & $\begin{array}{c}30.0- \\
39.99 \mathrm{~mm}\end{array}$ & $\begin{array}{c}40.0- \\
49.99 \mathrm{~mm}\end{array}$ & $\begin{array}{c}50.0- \\
59.99 \mathrm{~mm}\end{array}$ & $\begin{array}{c}60.0- \\
69.99 \mathrm{~mm}\end{array}$ & Total \\
\hline \multirow{4}{*}{ HC1 } & Chert & 0 & 9 & 18 & 8 & 1 & 0 & 0 & 36 \\
\hline & Silcrete & 0 & 15 & 41 & 27 & 8 & 2 & 1 & 94 \\
\hline & Other & 0 & & 1 & 0 & 1 & 0 & 0 & 2 \\
\hline & Total & $\mathbf{0}$ & 24 & 60 & 35 & 10 & 2 & 1 & 132 \\
\hline \multirow{4}{*}{ HC2 } & Chert & 0 & 2 & 5 & 1 & 3 & 2 & 0 & 13 \\
\hline & Silcrete & 1 & 12 & 17 & 11 & 2 & 0 & 1 & 44 \\
\hline & Other & 0 & 0 & 0 & 0 & 0 & 0 & 0 & 0 \\
\hline & Total & 1 & 14 & 22 & 12 & 5 & 2 & 1 & 57 \\
\hline \multirow{4}{*}{ HC3 } & Chert & 0 & 1 & 6 & 2 & & 1 & 0 & 10 \\
\hline & Silcrete & 0 & 8 & 12 & 5 & 4 & 3 & 0 & 32 \\
\hline & Other & 0 & 0 & 0 & 0 & 0 & 0 & 0 & 0 \\
\hline & Total & $\mathbf{0}$ & 9 & 18 & 7 & 4 & 4 & $\mathbf{0}$ & 42 \\
\hline \multicolumn{2}{|c|}{$\begin{array}{l}\text { Total (all three sites } \\
\text { combined) }\end{array}$} & 1 & 47 & 100 & 54 & 19 & 8 & 2 & 231 \\
\hline
\end{tabular}


Table 12. Retouch invasiveness index by raw material type.

\begin{tabular}{|c|c|c|c|c|c|}
\hline & & \multicolumn{4}{|c|}{ Raw Material } \\
\hline Site & $\begin{array}{l}\text { Number of } \\
\text { Retouched } \\
\text { Segments }\end{array}$ & Other & Chert & Silcrete & Total \\
\hline \multirow{7}{*}{ HC1 } & 1 & 1 & 18 & 35 & 54 \\
\hline & 2 & 0 & 3 & 13 & 16 \\
\hline & 3 & 0 & 7 & 3 & 10 \\
\hline & 4 & 0 & 0 & 3 & 3 \\
\hline & 5 & 0 & 4 & 2 & 6 \\
\hline & 7 & 0 & 2 & 0 & 2 \\
\hline & Total & 1 & 34 & 56 & 91 \\
\hline \multirow{7}{*}{ HC2 } & 1 & 0 & 6 & 24 & 30 \\
\hline & 2 & 0 & 4 & 11 & 15 \\
\hline & 3 & 0 & 3 & 4 & 7 \\
\hline & 4 & 1 & 2 & 4 & 7 \\
\hline & 5 & 0 & 0 & 2 & 2 \\
\hline & 6 & 0 & 0 & 1 & 1 \\
\hline & Total & 1 & 15 & 46 & 62 \\
\hline \multirow{9}{*}{ HC3 } & 1 & 0 & 7 & 16 & 23 \\
\hline & 2 & 0 & 4 & 10 & 14 \\
\hline & 3 & 0 & 2 & 3 & 5 \\
\hline & 4 & 1 & 3 & 2 & 6 \\
\hline & 5 & 0 & 0 & 3 & 3 \\
\hline & 6 & 0 & 0 & 1 & 1 \\
\hline & 7 & 0 & 0 & 1 & 1 \\
\hline & 13 & 0 & 1 & 0 & 1 \\
\hline & Total & 1 & 17 & 36 & 54 \\
\hline \multicolumn{2}{|c|}{$\begin{array}{l}\text { Total (all three sites } \\
\text { combined) }\end{array}$} & 3 & 66 & 138 & 207 \\
\hline
\end{tabular}

Table 13. Core:flake ratios by raw material type.

\begin{tabular}{|c|c|c|c|c|}
\hline Site & Raw Material & Number of Cores & Number of Flakes & Core:Flake Ratio \\
\hline \multirow{4}{*}{ HC1 } & Chert & 36 & 111 & $1: 3.1$ \\
\hline & Silcrete & 94 & 168 & 1:1.8 \\
\hline & Other & 2 & 3 & 1:1.5 \\
\hline & Total & 132 & 282 & 1:2.1 \\
\hline \multirow{4}{*}{ HC2 } & Chert & 13 & 37 & $1: 2.8$ \\
\hline & Silcrete & 44 & 113 & $1: 2.6$ \\
\hline & Other & 0 & 1 & NA \\
\hline & Total & 57 & 151 & $1: 2.6$ \\
\hline \multirow{4}{*}{ HC3 } & Chert & 10 & 43 & 1:4.3 \\
\hline & Silcrete & 32 & 86 & $1: 2.7$ \\
\hline & Other & 0 & 2 & NA \\
\hline & Total & 42 & 131 & 1:3.1 \\
\hline \multirow{4}{*}{$\begin{array}{l}\text { Total (all } \\
\text { three sites } \\
\text { combined) }\end{array}$} & Chert & 59 & 191 & $1: 3.2$ \\
\hline & Silcrete & 170 & 367 & $1: 2.2$ \\
\hline & Other & 2 & 6 & $1: 3.0$ \\
\hline & Total & 231 & 564 & $1: 2.4$ \\
\hline
\end{tabular}



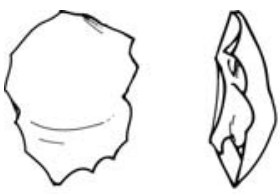

Artefact $\$ 122$

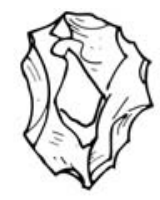

a)
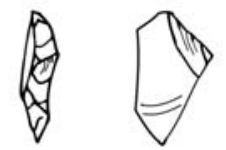

Artefact \#587
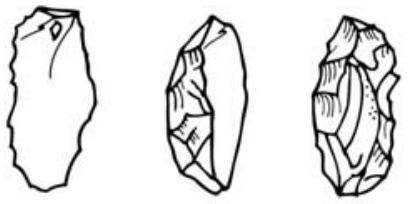
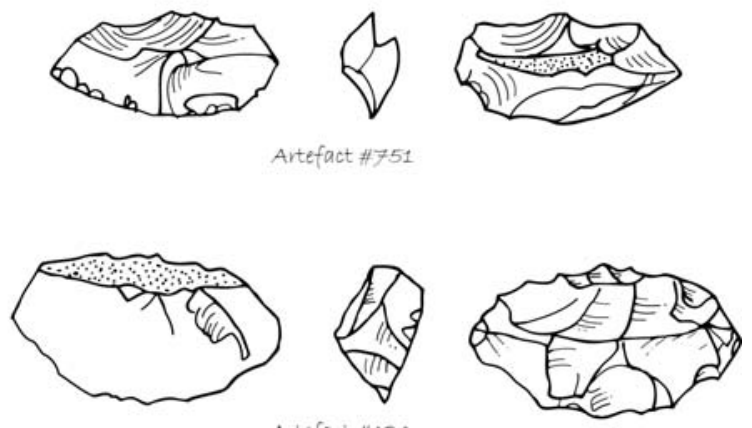

Artefact \#124
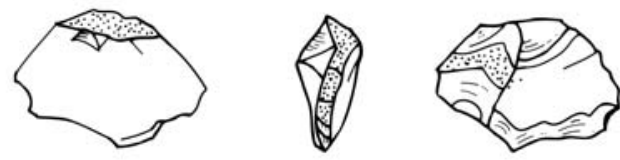

Artefact \#620

Figure 8. Illustrations of the six 'formal' retouched artefacts from the Bora Station assemblages. Note that Artefact \#587 has been drawn showing dorsal to ventral views (rather than ventral to dorsal) so as to allow the backed margin to be shown.

\section{Stone Artefact Analyses - Formal Tool Types}

Of all 1011 artefacts sampled for analysis, only six could be classified as 'formal types', three from HC1 and three from HC3 (Figure 8):

- Artefact 122 is a small yellow silcrete point, with retouch affecting the entire periphery of the edge. Retouch is unifacial only, emanating from the ventral to the dorsal surface.

- Artefact 123 is made from orange chert and is also heavily retouched along the entire periphery. Again, retouch is unifacial only and emanates from the ventral to the dorsal surface. Major retouch is along the lateral margins resulting in very steep edge angles forming a laterally retouched 'slug' (under traditional Australian typological schemes this artefact would be classified as a burin adze as the retouch is positioned parallel to the flake path).

- Artefact 124 is also made from chert and is heavily retouched unifacially. Retouch began distally and has continued until leaving a small slug at the proximal end of what was originally quite a large flake. Retouch is extremely heavy and covers almost the entire dorsal surface.

- Artefact 587 is a partially backed silcrete flake.

- Artefact 620 is a heavily retouched chert flake. Retouch is unifacial and begins distally continuing on to leave a small slug at the proximal end.

- Artefact 751 is a heavily retouched chert flake. Retouch is unifacial and occurs at both the proximal and distal ends with a heavier emphasis on distal retouch. Of all the flakes from HC3, this artefact was the most heavily retouched.

The presence of these artefacts at HC1 and HC3 suggests that knappers using these areas took the opportunity to retool here, discarding exhausted artefacts that were no longer capable of further reduction and producing new ones for use elsewhere.

\section{Discussion}

Heat retainer hearths are a common site type in the semiarid regions of the Australia, and this is especially so in the MGD (Wallis 2003; Wallis et al. 2004). Despite their containing abundant heat retainer stones, several of the excavated hearths at Bora did not preserve any organic materials; this is not an uncommon situation owing to taphonomic processes (cf. Holdaway et al. 2000; Simmons 2002; Wallis et al. 2004). Previous radiocarbon dating of hearths at Richmond, c. $100 \mathrm{~km}$ to the north of Bora, revealed uncalibrated age estimates between 240 and 870 years BP (Wallis 2003; Wallis et al. 2004). These were interpreted as indicating that c.1000 BP was a minimal age for Aboriginal occupation of the northeastern MGD region, though as Wallis et al. (2004:71) point out, this gave 'no indication of when the area might first have been used'. The Bora radiocarbon chronology shows repeated use of the Rupert Creek area since at least 2000 BP. A cache of tula adzes near Boulia with a midHolocene date (Hiscock 1988) provides evidence that Aboriginal use of the wider MGD plains is indeed older.

Unlike hearths, middens are rarely reported archaeologically - to 1990 only one midden site had been recorded in the MGD (Border and Rowland 1990:56). Nevertheless, most explorers' accounts made regular mention of the observance of freshwater mussel shell middens and their dietary importance. For example:

we came to a creek with a long, broad, shallow waterhole. The well worn path, the recent tracks of natives, and the heaps of shells, on the contents of which the latter had feasted, showed at once that this creek must be connected with some creek of considerable importance (Anon. 1861:18, Camp 84).

This place seems to be a favourite resort for blacks; the banks are covered with mussels, and all the firewood burned (Landsborough 1862:39). 
Roth (1897:93-94) made similar observations in the following decades, noting the shells were usually roasted whole after having been retrieved from muddy creeks by using the feet to feel for them. While there can be no doubt that the absence of archaeologically-documented middens in the MGD is at least partially due to an absence of systematic surveys being carried out in the region, it is worth pointing out that the ever-increasing numbers of cultural heritage clearance surveys conducted in the region in the past 15 years have rarely recorded such sites either. Given the extremely limited appearance of shells on the surface at Bora, despite their well-preserved presence in the subsurface context, it is clear that that these sites are extremely vulnerable to physical destruction through treadage by sheep and cattle. Once trampled, the remaining shell fragments are extremely lightweight, and also vulnerable to removal through wind and water action. We argue that the chances of finding large midden sites, such as described by early explorers and pastoralists in this region, intact at ground surface level is minimal except in exceptional circumstances.

Open area excavation of M1 or M2 at Bora was not undertaken and hence little can be said about their extent or whether they contained materials other than mussel shell. However, it can be stated that when shell was being collected from these exposures no other in situ materials were observed. Likewise, while the excavation of M3 was extremely limited, the only materials recovered were shells of a single species (Velesunio sp.). These were almost certainly gathered from the nearby Rupert Creek, probably at the start of the dry season when the creek would still have held sufficient water from the wet season rains to support a mussel population but when the ground surface had dried out sufficiently to allow travel across the Downs. Local pastoralists report that even after lengthy periods of drought, when rains finally arrive the local creeks quickly fill with mussels, suggesting they can survive long periods of dormancy (M. Kersh, pers. comm., 2004).

Burials have also been only rarely reported in the MGD though, as this feature of the site has been dealt with in detail elsewhere (Domett et al. 2006) it is not considered further here, except to note the unusual proximity of the burial to the occupation site. Burials are rare in the MGD, a factor in part due to the reluctance of pastoralists to report the presence of such sites owing to unfounded fears about their potential implications for land tenure, the limited amount of systematic survey undertaken in the region and the harsh environmental conditions which rapidly destroy organic materials when exposed to the elements.

While the presence of abundant surface stone assemblages in the MGD is well-documented (e.g. Bird 1997, 2000a, 2000b, 2000c; Border 1992; Horsfall 1988; Spencer 1994; Wallis 2011b), detailed analyses are absent, though the following general features have been argued to be typical for the region:

- the majority of such sites comprise low density, surface concentrations;

- $\quad$ silcrete is the dominant raw material, followed by chert, with some evidence of the use of basalt, quartz and quartzite;
- $\quad$ assemblages are dominated by unretouched flakes and cores, with few formal tools;

- most sites are situated either on elevated ridges or creek terraces near major watercourses;

- concentrations are regularly associated with hearths, which typically present as deflated areas of burnt mudstone; and,

- many sites have been disturbed by natural erosion processes, cattle trampling or modern development.

The Bora assemblage conforms to most of these generalisations, with the exception of the relatively high levels of retouched artefacts observed. This point of difference may be merely a function of earlier descriptive cultural heritage management-driven studies not having been sufficiently detailed to identify the retouched component. Otherwise the most obvious and interesting feature of the Bora assemblage is the heavy weathering apparent on almost every artefact, a situation not otherwise reported in consulting project reports. Given their location adjacent to an ephemeral stream it is likely that these artefacts have been repeatedly submerged during wet season flooding, a process which appears to have also resulted in the removal of many small flakes, leaving a size-biased assemblage. From an analytical perspective, the most important feature of the weathering is that it facilitates the identification of the recycling of artefacts through time. Between $15 \%$ and $25 \%$ of the total number of flakes and cores show signs of multiple knapping events (up to three) with weathering in-between. Sometimes an unretouched flake has been produced and then been used as a core or retouched by another knapper sufficiently long thereafter to allow a weathered surface to develop. Consequently, flakes with scars along the margins that have obviously been produced many years later, must be technologically categorised as retouched flakes, despite being the product of use by several knappers over an extended period of time and for a range of unrelated purposes. These high levels of recycling are likely to be responsible for the high numbers of retouched artefacts in the assemblage, as well as the low invasiveness levels of that retouch with often only one or two scars resulting in a 'retouched' classification.

As indicated by the site extent, artefact densities and numbers of hearths present, the reuse and recycling of lithics supports the notion that the area is the product of repeated visits by small groups over an extended period of time. The site therefore represents a palimpsest in which many years are compressed into the one chronologically indistinguishable assemblage. This is not surprising given the environmental conditions. While wet season flooding can cause silt to be deposited, the long drought periods coupled with windiness serves to counter any potential sediment accumulation, resulting in net sediment loss through time. The continual removal of sediment would maintain the same exposure of artefacts for many years, coupled with the reuse of old materials and the addition of new materials occurring with each new visit, an accurate picture of what people might have been doing during each visit is not possible.

Given the effects of reuse and recycling on the HC1, HC2 and HC3 assemblages it is not surprising that they appear so similar, with continued weathering and 
recycling events over extended periods of time blending any unique effects of individual visits or the possibility that differential activities were carried out at each locality. At all three localities the stone assemblages are dominated by silcrete and chert with only a small number of other raw materials utilised. With the exception of a slightly higher proportion of chert at HC3, relative proportions of silcrete and chert are comparable between the locations. Differences in the treatments of raw materials in terms of the production of particular artefact classes or correlations between the sizes of artefacts and the raw materials from which they are made are also not detectable at any of the three locations.

While reduction indices from HC1, HC2 and HC3 are largely comparable, slightly greater levels of reduction are evidenced on the dorsal surfaces of chert flakes and in a slightly increased reduction of chert cores from HC3. Despite the presence of comparatively large numbers of cores at all three sites, the consistently high levels of secondary decortication evidenced indicates only moderate levels of reduction were occurring, with most cores discarded before being exhausted. The high proportions of retouched flakes in the Bora assemblages have also been shown to have low retouch invasiveness indexes, with retouch affecting only one or two segments of the edge in most cases. The formal tools types recovered represent a handful of exceptions and support an argument for periodic retooling at these sites.

Core:flake ratios clearly show that raw materials were being transported across the landscape, be it by knappers or post-depositional processes. Although only of the grossest nature, it is worth extrapolating these figures to make an estimate of how many artefacts might occur in total across the three localities along Rupert Creek in order to help assess whether it is likely that these areas were home to a semi-sedentary population as has been suggested. These calculations suggest there may be as many as 155,000, 424,000 and 181,000 artefacts at HC1, HC2 and HC3, respectively. If it is assumed the area has been utilised for at least 2000 years as suggested by the available radiocarbon chronology, this represents an average of just over one artefact being deposited in the area per day per year; we would argue that these rates of deposition are highly unlikely to be the result of semipermanent occupation or even annual visitation to the area, but rather a much more sporadic use.

\section{Conclusion}

As Holdaway et al. (2006:10) have discussed with reference to the arid zone of New South Wales, hearths represent one of our few opportunities for dating open sites. The ongoing destruction of these archaeological features threatens the integrity of the archaeological record and our ability to develop an understanding of the complexity of Aboriginal occupation of inland Australia, including the MGD of northwest Queensland, not to mention the significance to Aboriginal people of the loss of yet more of their tangible cultural heritage; this is a substantial management concern that requires addressing (Moffat et al. 2008). The investigation of a series of exposed but not yet entirely destroyed hearth features at an open site complex in inland northwest Queensland has allowed us to establish a minimum age for use of this area.
Conclusions about the movement of people, raw materials and stone artefacts across the landscape at Bora have been difficult to determine, with a single neat explanation of the overall site and stone artefact assemblage formation and what they mean in terms of human use of the MGD not easy. The Bora Station stone artefact assemblages are clearly the product of human activity over a number of years, compressed into a single surface archaeological unit through active postdepositional processes. Extensive reuse and recycling of artefacts over hundreds of years makes interpretation of the scatters at any one time impossible and has resulted in over inflated frequencies of retouched artefacts. However, some consistent patterns are apparent:

- Low to moderate levels of reduction are evident within each scatter.

- Recycling and reuse of materials implies that the scatters were visited repeatedly, probably seasonally.

- Given the length of time over which these scatters are likely to have been frequented, artefact numbers are quite low, suggesting only very short-term occupation of the area (based on the hearth and midden dates).

- The presence of a handful of formal tool types and intensively retouched artefacts and small unretouched flakes at the site suggests low-level retooling did occur at times, discarding old artefacts and replacing them with new.

- Discrepancies between core scar numbers and flakes indicate not only that post-depositional processes have removed some flakes but that knappers may have consciously removed flakes from the site for retooling.

- The overall lack of intensively retouched items implies that for the most part, flakes were manufactured for expedient purposes only.

- Intensification of site use never reached desperate levels with suitable raw material always near enough not to necessitate dramatic conservation measures.

The density of stone artefacts in the area is extremely low, especially in comparison to open sites reported elsewhere in the semi-arid zone. As we have suggested by a coarsegrained extrapolation of artefact densities and the site chronology, it is unlikely that these assemblage represent anything more than very occasional visits to Rupert Creek. In fact, the very nature of the environmental conditions of the MGD would seem to indicate that occupation in this region would by necessity have probably been highly seasonal and, owing to the likelihood of waterholes of drying up, would have been extremely limited on an annual basis, towards the end of the dry season, as well as on a decadal or longer basis during times of extended drought.

\section{Acknowledgements}

This research was funded by an Australian Institute of Aboriginal and Torres Strait Islanders Studies research grant (G2004/6898) and conducted under permits issued by the then Environmental Protection Agency (CHCG00077804 and CHCC00078004). Ethical approval for the project was granted from the Human Research Ethics Committee of the Australian National University. James Cook University, Flinders 
University and ANU provided logistical support and equipment during the various field seasons. The authors would like to thank the members of the Woolgar Valley Aboriginal Corporation who granted permission for this work to be undertaken and showed such enthusiasm for fieldwork. In particular, Helen Smith, Allan Kynuna (now deceased), John Keyes, Darren Kynuna, Mick Smith and Roshani Smith were keen participants during the seemingly endless days of surveying, recording and excavating; volunteers Mark O’Callaghan and Peter Cogan also provided assistance. John Richter and Andrew Border are also thanked for sharing their knowledge about the local area and their encouragement in pursuing this research. Thanks to Alice Gorman for drawing the artefacts shown in Figure 8. Finally, the former and current owners of Bora Station, the Kersh family, are especially thanked for their hospitality and assistance during fieldwork, and their willingness to allow archaeological research to be conducted on their property. This paper is dedicated to Matt Kersh, who died in a tragic accident a few years after this project was undertaken.

\section{References}

Allingham, A. 1988 "Taming the Wilderness": The First Decade of Pastoral Settlement in the Kennedy District. Studies in North Queensland History 1. Townsville: History Department, James Cook University of North Queensland.

Anon. 1861 The Burke and Wills Exploring Expedition: An Account of the Crossing of the Continent of Australia, from Cooper's Creek to Carpentaria (reprinted from The Argus). Melbourne: Wilson and Mackinnon. [Facsimile Edition 1963, Libraries Board of South Australia, Adelaide].

Bamforth, D.B. 1986 Technological efficiency and tool curation. American Antiquity 51(1):38-50.

Bird, M. 1997 Report on the Archaeological Survey and Assessment of a Proposed $66 \mathrm{kV}$ Transmission Line, Richmond-Julia Creek, North West Queensland. Unpublished report to North Queensland Electricity Corporation, Townsville.

Bird, M. 2000a Progress Report \#8 to Ergon Energy Cultural Heritage Reconnaissance Mid-Western SWER Powerline Refurbishment Project Glenelg SWER Area October 1999. Unpublished report to Ergon Energy Corporation, Townsville and the Winton District Aboriginal Corporation.

Bird, M. 2000b Progress Report \#10 to Ergon Energy Cultural Heritage Reconnaissance Mid-Western SWER Powerline Refurbishment Project Richmond South SWER Area AprilJune 2000. Unpublished report to Ergon Energy Corporation, Townsville and the Wanamara Traditional Owners.

Bird, M. 2000c Progress Report \#13 to Ergon Energy Cultural Heritage Reconnaissance Mid-Western SWER Powerline Refurbishment Project Maxwelton South SWER Area, Richmond District, May-July 2000. Unpublished report to Ergon Energy Corporation, Townsville, and Wanamara Traditional Owners.

Border, A. 1992 An Archaeological Study in the Central Downs Sub-Region of the Mitchell Grass Downs Biogeographic Zone, Queensland. Unpublished report to Department of Environment and Heritage, Brisbane and Australian Heritage Commission, Canberra.

Border, A. and M. Rowland 1990 The Mitchell Grass Downs Biogeographic Zone (Queensland): A Heritage Resource Assessment. Unpublished report to Heritage Branch, Department of Environment and Heritage, Brisbane and Australian Heritage Commission, Canberra.

Burbidge, N.T. 1984 Australian Grasses. London: Angus and Robertson Publishers.
Chisolm, J.R. 1901 Aboriginal instruments and notes. Journal of Science of Man 4:80.

Chisolm, J.R. 1903 Aboriginal drawings. Journal of Science of Man 5:193.

Clarkson, C. 2002 An index of invasiveness for the measurement of unifacial and bifacial retouch: A theoretical, experimental and archaeological verification. Journal of Archaeological Science 29:65-75.

Crothers, L. 1997 A Documentation of Aboriginal Cultural Heritage Sites Located in the Richmond Region, Northwest Queensland. Unpublished report to Central Queensland Aboriginal Land Council.

Davidson, I., S.A. Sutton and S.J. Gale 1993 The human occupation of Cuckadoo 1 Rockshelter, northwest central Queensland. In M.A. Smith, M. Spriggs and B. Fankhauser (eds), Sahul in Review: Pleistocene Archaeology in Australia, New Guinea and Island Melanesia, pp.164-172. Occasional Papers in Prehistory 24. Canberra: Department of Prehistory, Research School of Pacific and Asian Studies, Australian National University.

Domett, K.M., L.A. Wallis, D. Kynuna, A. Kynuna and H. Smith 2006 Late Holocene human remains from northwest Queensland, Australia: Archaeology and palaeopathology. Archaeology in Oceania 41(1):25-36.

Eden, C.H. 1872 My Wife and I in Queensland: An Eight Year Experience in the Above Colony with Some Account of Polynesian Labour. London: Longmans, Green.

Gray, R. 1913 Reminiscences of India and North Queensland. London: Constable and Co.

Hiscock, P. 1988 A cache of tulas from the Boulia District, western Queensland. Archaeology in Oceania 23(2):60-70.

Hiscock, P. 2006 Looking the other way: A materialist/technological approach to classifying tools and implements, cores and retouched flakes, with examples from Australia. In S. McPheron and J. Lindley (eds), Tools or Cores? The Identification and Study of Alternative Core Technology in Lithic Assemblages, pp.198-222. Philadelphia: University of Pennsylvania Museum.

Holdaway, S. and N. Stern 2004 A Record in Stone: The Study of Australia's Flaked Stone Artefacts. Canberra: Aboriginal Studies Press.

Holdaway, S.J., P.C. Fanning and J. Shiner 2006 Geoarchaeological Investigation of Aboriginal Landscape Occupation in Paroo-Darling National Park, Western NSW, Australia. Research in Anthropology and Linguistics Monograph 1. Auckland: Department of Anthropology, University of Auckland.

Holdaway, S.J., P.C. Fanning and D.C. Witter 2000 Report of the Western New South Wales Archaeology Project. Unpublished report to NSW National Parks and Wildlife Service, Sydney.

Holmes, J.M. 1963 Australia's Open North: A Study of Northern Australia Bearing on the Urgency of the Times. Sydney: Angus and Robertson.

Horsfall, N. 1988 Archaeological Survey of a Proposed Powerline to Stations between Burketown and Normanton. Unpublished report to Far North Queensland Electricity Board.

Landsborough, W. 1862 Journal of Landsborough's Expedition from Carpentaria, in Search of Burke and Wills. Melbourne: F.F. Bailliere. 
Laurie, J.S. (ed.). 1866 Landsborough's Exploration of Australia from Carpentaria to Melbourne, with Especial Reference to the Settlement of Available Country. London: Thomas Murby.

Lowe, K.M. and L.A. Wallis 2012 Aboriginal Cultural Heritage Site Assessment of Drill Pads in Petroleum Exploration Tenement ATP974P near Richmond, Northwest Galilee Basin, North Queensland. Unpublished report to Westside Corporation Pty Ltd.

McCormac, F.G., A.G. Hogg, P.G. Blackwell, C.E. Buck, T.F.G. Higham and R.P. Reimer 2004 SHCal04 Southern Hemisphere calibration 0-1000 cal. BP. Radiocarbon 46:1087-1092.

McKinlay, J. 1861-1862 Journal of Explorations in the Interior of Australia (Burke Relief Expedition). Melbourne: Bailliere [Facsimile Edition, 1962].

Meston, A. 1895 Geographic History of Queensland. Brisbane: Government Printer.

Moffat, I., L.A. Wallis, A. Beale and D. Kynuna 2008 Trialing geophysical techniques in the identification of open Indigenous sites in Australia: A case study from inland northwest Queensland. Australian Archaeology 66:60-63.

Neldner, V.J. 1991 Vegetation Survey of Queensland. Queensland Botany Bulletin 9. Brisbane: Queensland Department of Primary Industries.

Perry, R.A. 1964 Part II. Summary description of the Leichhardt-Gilbert area. In R.A. Perry (ed.), General Report on the Lands of the Leichhardt-Gilbert Area, Queensland 1953-54, pp.16-24. Land Research Series 11. Melbourne: CSIRO.

Perry, R.A. and M. Lazarides 1964 Part IX. Vegetation of the Leichhardt-Gilbert area. In R.A. Perry (ed.), General Report on the Lands of the Leichhardt-Gilbert Area, Queensland 1953-54, pp.152-91. Land Research Series 11. Melbourne: CSIRO.

Rosendahl, D. and L.A. Wallis 2011 Aboriginal Cultural Heritage Survey: NW01 and NW02, Richmond, Queensland. Unpublished report to Westside.

Roth, W.E. 1897 Ethnological Studies among the North-WestCentral Queensland Aborigines. Brisbane: Government Printers.

Rowland, M.J., A. Border and J.R. Smith 1994 Archaeological research and management: A biogeographical approach. Australian Archaeology 38:23-28.

Simmons, A. 2002 An analysis of hearths in open sites on the Diamantina River, Queensland. In S. Ulm, C. Westcott, J. Reid, A. Ross, I. Lilley, J. Prangnell and L. Kirkwood (eds), Barriers, Borders, Boundaries: Proceedings of the 2001 Australian Archaeological Association Annual Conference, pp.75-80. Tempus 7. Brisbane: Anthropology Museum, University of Queensland.
Slatyer, R.O. 1964 Climate of the Leichhardt-Gilbert area. In R.A. Perry (ed.), General Report on the Lands of the Leichhardt-Gilbert Area, Queensland 1953-54, pp.90-104. Land Research Series 11. Melbourne: CSIRO.

Spencer, T. 1994 A Documentation of Archaeological Sites on the 1:250 000 Sheets for Richmond, Julia Creek, Camooweal and some Adjoining Areas. Unpublished report to Queensland Museum, Brisbane.

Twidale, C.R. 1966 Geomorphology of the Leichhardt-Gilbert Area of Northwest Queensland. Land Research Series 16. Melbourne: CSIRO.

Vine, R.R. 1970 1:250,000 Geological Series, Explanatory Notes: Richmond, Queensland (Sheet SF/54-5). Canberra: Bureau of Mineral Resources.

Walker, F. 1862 Diary of Expedition. Original manuscript held in National Library of Australia, Canberra.

Wallis, L.A. 2003 Archaeological Investigations in Wanamara Country, Northwest Queensland, Aug-Oct 2002. Unpublished report to Australian Institute of Aboriginal and Torres Strait Islander Studies, Canberra and Woolgar Valley Aboriginal Corporation.

Wallis, L.A. 2011a Aboriginal Cultural Heritage Survey of Drill Pad Locations on Burleigh, Coalbrook, Grampian Valley and Rainscourt Stations, North Queensland. Unpublished report to Linc Energy.

Wallis, L.A. 2011b Aboriginal Cultural Heritage Survey of Transmission Line Easement South of the Flinders Highway between Richmond and Julia Creek, Wanamara People Core Country Claim area, north Queensland. Unpublished report to VisionStream.

Wallis, L.A. 2011c Aboriginal Cultural Heritage Survey of Drill Pad Locations near Julia Creek and Richmond, Queensland. Unpublished report to Linc Energy.

Wallis, L.A., B. Keys, I. Moffat and S. Fallon 2009 Gledswood Shelter 1: Initial radiocarbon dates from a Pleistocene aged rockshelter site in northwest Queensland. Australian Archaeology 69:71-74.

Wallis, L.A., H. Smith and D. Smith 2004 Investigations of Aboriginal hearth sites along the Flinders River, inland north west Queensland. The Artefact 27:59-76.

Wright, B. 1988 Between Two Rivers: The Aborigines of the Leichhardt-Gilbert Region of North West Queensland. Cultural Resource Management Monograph Series 7. Brisbane: Archaeology Branch, Department of Community Services. 
